\title{
1,2,3-Triazole-Functionalized Polysulfone Synthesis through Micro- wave-Assisted Copper-Catalyzed Click Chemistry: a Highly Proton Conducting High Temperature Membrane
}

\author{
Rakhi Sood, Anna Donnadio, Stefano Giancola, Aurélien Kreisz, Deborah J. Jones, Sara Cavaliere*
}

Institut Charles Gerhardt Montpellier, UMR CNRS 5253, Agrégats Interfaces et Matériaux pour l'Energie, Université de Montpellier - 34095 Montpellier Cedex 5, France.

*Corresponding author: Fax: +33 (o) 4671433 04; Tel: +33 (o)4 6714 90 98; E-mail: sara.cavaliere@umontpellier.fr

Keywords: microwave-assisted synthesis, click-chemistry, copper-catalyzed azide-alkyne cycloaddition, 1,2,3-triazole functionalized polysulfone, high temperature proton exchange membrane fuel cells, phosphoric acid doped membranes.

\begin{abstract}
Microwave heating holds all the aces regarding development of effective and environment-friendly methods to perform chemical transformations. Coupling the benefits of microwave-enhanced chemistry with highly reliable coppercatalyzed azide-alkyne cycloaddition (CuAAC) click chemistry paves the way for a rapid and efficient synthesis procedure to afford high-performance thermoplastic materials. We describe herein fast and high-yielding synthesis of 1,2,3-triazole functionalized polysulfone through microwave-assisted CuAAC as well as explore their potential as phosphoric acid doped polymer electrolyte membranes (PEM) for high temperature PEM fuel cells. Polymers with various degrees of substitution of the side-chain functionality of 1,4-substituted 1,2,3-triazole with alkyl and aryl pendant structures are prepared by sequential chloromethylation, azidation and microwave-assisted CuAAC using a range of alkynes (1-pentyne, 1-nonyne and phenylacetylene). The completeness of reaction at each step as well as the purity of the clicked polymers were confirmed by ${ }^{1} \mathrm{H}^{-13} \mathrm{C}$ NMR, DOSY-NMR and FTIR-ATR spectroscopies. The thermal and thermo-chemical properties of the modified polymers were characterized by differential scanning calorimetry and thermogravimetric analysis coupled with mass spectroscopy (TG-MS) respectively. TG-MS analysis demonstrated that the commencement of the thermal degradation takes place with the decomposition of the triazole ring while its substituents have critical influence on the initiation temperature. Polysulfone functionalized with 4-phenyl-1,2,3-triazole demonstrate significantly higher $\mathrm{T}_{\mathrm{g}}, \mathrm{T}_{\mathrm{d}}$ and elastic modulus than the ones bearing 4-propyl-1,2,3-triazole and 4-heptyl-1,2,3-triazole groups. After doping with phosphoric acid, the functionalized polymers with ADL of 5 show promising performance with high proton conductivity in anhydrous conditions (in the range of $27-35 \mathrm{mS} / \mathrm{cm}$ ) and satisfactorily high elastic modulus (in the range of 332-349 MPa).
\end{abstract}

\section{Introduction}

The 1,2,3-triazole functionality demonstrates high chemical stability towards severe hydrolytic, oxidizing, and reducing conditions, even at elevated temperatures, as well as aromatic character and the ability to form hydrogen bonds, and antioxidant, anti-microbial and medicinal properties, amongst others. ${ }^{1-5}$ Due to these features, materials functionalized with 1,2,3-triazole are of interest for a variety of industrial and medicinal applications. Since the remarkable development of the copper-catalyzed azide-alkyne cycloaddition (CuAAC) modular ligation by Sharpless ${ }^{6}$ and $\mathrm{Meldal}^{7}$, the $\mathrm{CuAAC}$ reaction has been extensively used as a tool for the elaboration of various polymers with advanced macromolecular design, including telechelic polymers, block copolymers, dendrimers etc. $7^{-22}$ To extend the range of applications of polymers with the 1,2,3triazole functionality, it is crucial to extend the library of materials which capitalize on the important properties of 1,2,3triazole, by varying structural parameters including the nature of the polymer backbone, pendant chain structures and triazole-ring substituents. This will permit more precise understanding of the interplay of structure and properties in order 
to develop high performance materials with properties fine-tuned according to the requirements of the application. Recently, synthesis of 1,2,3-triazole functionalized poly- vinyls 3 , acrylates ${ }^{23,24}$, ionenes ${ }^{25}$ and siloxanes ${ }^{26}$ through CuAAC chemistry have been reported for application in dye sensitized solar cells, fuel cells, batteries and electrochromic devices. Ideally, the CuAAC reaction is carried out at room temperature and produces high yields in short reaction times ${ }^{27}$. However, in some cases, it has been found to be very slow and to require elevated temperatures and/or long times for its completion..$^{28}$ The advent of Microwave-Assisted Organic Synthesis (MAOS) has enabled not only significantly accelerated rate of chemical transformations but also cleaner products, with higher yields, by avoiding unwanted side reactions. ${ }^{27}$ Similarly, the implementation of microwave heating in CuAAC reactions has led to remarkable improvement in the yields and the reaction times. ${ }^{27,29}$ In particular, microwave assisted-CuAAC (MA-CuAAC) has been successfully utilized for organic synthesis, supra-molecular chemistry and synthesis of carbohydrates as well as oligonucleotide analogues. ${ }^{27,30}$ Nonetheless, the application of microwave heating in macromolecular synthesis remains very limited up to now.

The introduction of facile and efficient MA-CuAAC chemistry for the production of high performance aromatic thermoplastics bearing a highly stable basic functionality would be an elegant strategy for the development of functionalized materials for a variety of applications. For instance, due to the presence of a pendant heterocyclic group, such polymers are expected to be proton conducting and could find application as membrane materials in Proton Exchange Membranes Fuel Cells (PEMFC) operating under quasi-anhydrous conditions at temperatures above those where perfluorosulfonic acid ionomers such as Nafion ${ }^{\circ}$ or Aquivion ${ }^{\circ}$ can be used. Although practicable at lower temperatures, water management in a fuel cell at temperatures higher than $100{ }^{\circ} \mathrm{C}$ has a significant impact on the viability of the membrane electrode assembly (MEA) and on overall operation of the system. Over the last decade, new concepts have evolved involving alternative proton carriers that mark a move towards reducing the need for high levels of hydration. By replacing water as a proton carrier by $\mathrm{N}$ heterocycles such as imidazole ${ }^{31,32}$, pyrazole ${ }^{32}$, benzimidazole or triazole ${ }^{33}$, the conductivity is expected to be less dependent on water content, since proton transfer between heterocycles is an intrinsic property of these systems. The relevance of these concepts was shown elegantly by Kreuer, in particular in pioneering work on imidazole - sulfonated poly(ether ketone) type ionomers. ${ }^{34}$ Similarly, Zhou and co-workers described membranes of sulfonated polysulfone impregnated with $1 \mathrm{H}-1,2,3$-triazole as solvent. ${ }^{35}$ Immobilization of the heterocycle on a polymer is essential to avoid leaching from the polymer matrix over the course of time. A number of model compounds have been described, in which heterocycles are linked through ethylene oxide oligomer ${ }^{31,36}$ or polysiloxane ${ }^{37}$ backbones. Steps towards increasing the concentration of charge carriers have been made by radiation induced grafting of polymeric 1-vinylimidazole on to ethylenetetrafluoroethylene $(\mathrm{ETFE})^{38}$ and by free radical induced polymerization of vinylimidazole on to divinylbenzene modified polybenzimidazole ${ }^{39}$. Steps towards increasing nanophase separation between the heterocycles and the polymer backbone have been described in recent work on the development of novel copolymers in which heterocycle is immobilized as a pendant group on a chlorotrifluoroethene backbone ${ }^{40-43}$. Guiver et al. have developed aromatic polymers functionalized with 1,2,3-triazole and 5-amino-benzotriazole groups for Alkaline Fuel Cell (AFC) and Direct Methanol Fuel Cell (DMFC) applications respectively. ${ }^{44,45}$ Sanghi et al. elaborated composite membranes of $1 \mathrm{H}-1,2,3$-triazole functionalized polysiloxanes in combination with trifluoroacetic acid/phosphoric acid and reported proton conductivity of $1.6 \mathrm{mS} / \mathrm{cm}$ at $180{ }^{\circ} \mathrm{C}$ for a membrane doped with 2.5 moles of phosphoric acid per polymer repeat unit. $4^{6}$

The nature of heterocycle and its substituents can have significant impact on thermal, mechanical, anti-oxidant properties.47-49 In this work, we have developed microwave assisted-CuAAC to synthesize 1,2,3-triazole functionalized polysulfones with various aliphatic and aromatic triazole ring substituents (propyl, heptyl and phenyl) in order to validate the feasibility and versatility of the synthesis route as well as to establish the interplay of structure-properties for the resulting polymers, which were characterized using ${ }^{1} \mathrm{H}^{-13} \mathrm{C}$ NMR, DOSY-NMR and FTIR-ATR spectroscopies as well as differential scanning calorimetry (DSC) and thermogravimetric analysis coupled with mass spectroscopy (TGA-MS). Those with high degrees of 4-heptyl-1,2,3-triazole and 4-phenyl-1,2,3-triazole functionalities were cast into membranes and doped with phosphoric acid and characterized for their proton conduction and mechanical properties. To the best of our knowledge, MA-CuAAC is here employed for the first time as a synthetic route to afford 1,2,3-triazole functionalized polysulfones and their phosphoric acid doped membranes.

\section{EXPERIMENTAL SECTION}

Materials. Chlorotrimethylsilane (TMCS, $\left.\mathrm{C}_{3} \mathrm{H}_{9} \mathrm{ClSi}, \geq 97.0 \%\right)$, p-formaldehyde powder $\left(\mathrm{HO}\left(\mathrm{CH}_{2} \mathrm{O}\right)_{n} \mathrm{H}, 95 \%\right)$, tin tetrachloride $\left(\mathrm{SnCl}_{4}, 98 \%\right)$, sodium azide $\left(\mathrm{NaN}_{3}, \geq 99 \%\right)$, diisopropylethylamine (DIPEA, $\left.\left[\left(\mathrm{CH}_{3}\right)_{2} \mathrm{CH}\right]_{2} \mathrm{NC}_{2} \mathrm{H}_{5}, 99 \%\right)$, 1-pentyne $\left(\mathrm{CH}_{3} \mathrm{CH}_{2} \mathrm{CH}_{2} \mathrm{C} \equiv \mathrm{CH}\right.$, 99\%), 1-nonyne $\left(\mathrm{CH}_{3}\left(\mathrm{CH}_{2}\right)_{6} \mathrm{C} \equiv \mathrm{CH}\right.$, 99\%), phenylacetylene $\left(\mathrm{C}_{6} \mathrm{H}_{5} \mathrm{C} \equiv \mathrm{CH}, 97 \%\right)$, copper(I) iodide triethylphosphite $\left(\mathrm{CuI} \cdot \mathrm{P}(\mathrm{OEt})_{3}, 97 \%\right)$, N,N,N',N",N"-pentamethyldiethylenetriamine (PMDETA, $\left[\left(\mathrm{CH}_{3}\right)_{2} \mathrm{NCH}_{2} \mathrm{CH}_{2}\right]_{2} \mathrm{NCH}_{3}$, 99\%), phosphoric acid solution $\left(\mathrm{H}_{3} \mathrm{PO}_{4}, 85 \mathrm{wt} \%\right.$ in $\left.\mathrm{H}_{2} \mathrm{O}\right)$ and all solvents were purchased from Aldrich and used as received. Polysulfone granules $(\mathrm{Mn}=8 \mathrm{o} \mathrm{KDa}$ and $\mathrm{Mw}=102 \mathrm{KDa})$ were purchased from Goodfellow. $26 \mathrm{wt} \%$ solution of poly[2,2'-(mphenylene)-5,5'-bibenzimidazole] ( $\mathrm{PBI} ; \mathrm{Mw}=35 \mathrm{KDa}$ ) in dimethylacetamide was purchased from PBI Performance Products. 
Characterization methods. NMR spectra were recorded on a Bruker Avance HD 40o MHz spectrometer equipped with a BBFO (Broad band fluorine observation) probe in DMF- $d_{6}$ using tetramethylsilane (TMS) as reference residual hydrogenated solvent. Peak multiplicities are designated as $\mathrm{m}=$ multiplet, $\mathrm{s}=$ singlet, $\mathrm{t}=$ triplet, br $=$ broad. Attenuated total reflection-infrared (ATR-IR) spectra were recorded with Horiba Jobin Yvon Labram Aramis instrument using a MCT Ir2 module detector and ATR 36x objective lens. Differential scanning calorimetry (DSC) measurements were performed under argon atmosphere using a Mettler Toledo DSC 1 at a heating rate of $10^{\circ} \mathrm{C} / \mathrm{min}$. $T_{\mathrm{g}}$ values were determined from the second heating cycle. Thermogravimetric analysis (TGA) was carried out under argon using a STA 449 F1 Jupiter (Netzsch) coupled with a mass spectrometer Aeolos III, at a heating rate of $10{ }^{\circ} \mathrm{C} / \mathrm{min}$. Acid doping level (ADL) i.e. number of phosphoric acid molecules per repeat unit of the polymer was determined using ion chromatography (Shimadzu HPLC apparatus equipped with a Shim-pack IC-Aı column and a conductivity detector; a flow rate of $1.5 \mathrm{~mL} \mathrm{~min}^{-1}$, an injection volume of $45 \mu \mathrm{L}$, a column temperature of $40^{\circ} \mathrm{C}$; with the mobile phase consisting of an aqueous solution of a mixture of $1.5 \mathrm{mmol} \mathrm{L}^{-1}$ phthalic acid

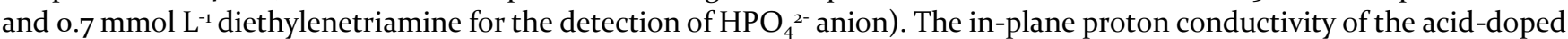
membranes was determined using a dry Fumatech $\mathrm{MK}_{3}$ impedance cell (equipped with a temperature controller) using a Keithley 2400 source meter in the temperature range $100-140{ }^{\circ} \mathrm{C}$. Stress-strain mechanical measurements were performed using a Zwick Roell Z1.o with a $200 \mathrm{~N}$ static load cell. The Young's modulus (the slope of the stress-strain curve in the elastic-deformation region), yield stress (maximum stress that can be developed without causing plastic deformation), stress at break (the tensile stress at the breaking point of the specimen), and elongation at break (the percentage increase in length that occurs before the sample breaks) were measured on rectangular (100 x $5 \mathrm{~mm}$ ) strips of membrane, obtained using a cutting machine. The thickness of the membrane was in the range $25-30 \mu \mathrm{m}$. An initial grip separation of 20.000 $\pm 0.002 \mathrm{~mm}$ and a crosshead speed of $30 \mathrm{~mm} \mathrm{~min}^{-1}$ were used. At least five replicate strips were analyzed. The data were treated by the TestXpert V11.o Master software.

Membrane preparation. Membranes were prepared by casting a solution of the polymer in chloroform or DMF on to a glass plate, followed by thermal treatment at $40{ }^{\circ} \mathrm{C}$ for 24 hours and then at $100{ }^{\circ} \mathrm{C}$ under vacuum for 2 hours to remove solvent and anneal the membrane. Phosphoric acid doped membranes were elaborated by immersion in $14.6 \mathrm{M}$ aqueous solution of $\mathrm{H}_{3} \mathrm{PO}_{4}$ at ambient temperature and at $110{ }^{\circ} \mathrm{C}$. The membranes were weighed at regular intervals (after being thoroughly blotted with paper) until stable weights were achieved. The acid uptake (AU\%) of the membrane was calculated in percent on the dry polymer basis as the ratio between the phosphoric acid content (Wpa) and the polymer content (Wp) of the membrane using the following equation:

$$
\boldsymbol{A U}(\%)=\left(\frac{\boldsymbol{W} \boldsymbol{p a}}{\boldsymbol{W p}}\right) * \mathbf{1 0 0}
$$

The dry weight of the polymer was determined by leaching out the phosphoric acid though immersion of the doped membrane in $50 \mathrm{ml}$ of $0.1 \mathrm{M}$ aqueous $\mathrm{NaOH}$ solution followed by drying the polymer at $8 \mathrm{o}^{\circ} \mathrm{C}$ under vacuum for $8 \mathrm{hours}$. The contribution of water uptake (WU\%) in the total uptake was determined on the dry polymer (Wp) plus phosphoric acid content (Wpa) basis by comparing the wet weight of the membrane after immersion in aqueous phosphoric acid solution (Wt) and the weight of dry polymer plus phosphoric acid ( $\mathrm{Wp}+\mathrm{Wpa}$ ) using the following equation:

$$
\boldsymbol{W U}(\%)=\left(\frac{\boldsymbol{W} \boldsymbol{t}-(\boldsymbol{W p}+\boldsymbol{W p a})}{(\boldsymbol{W p}+\boldsymbol{W p a})}\right) * \mathbf{1 0 0}
$$

The mass as well as area and volume swelling of the phosphoric acid doped membranes were calculated by measuring the dimensions of the membranes before and after swelling in the $\mathrm{H}_{3} \mathrm{PO}_{4}$ solution and using the following equation:

$$
\operatorname{Variation}(\%)=\left(D f-\frac{D i}{D i}\right) * 100
$$

where Di and Df stands for dimension of membrane before and after swelling respectively.

General Procedure for chloromethylation reaction. Synthesis of 2. A solution of polysulfone (1, $1 \mathrm{~g}, \mathbf{2 . 2 5} \mathrm{mmol})$, p-formaldehyde (0.68 g, $22.5 \mathrm{mmol})$ and $\mathrm{SnCl}_{4}(0.06 \mathrm{~g}, 0.24 \mathrm{mmol})$ in chloroform $(200 \mathrm{~mL})$ was stirred under nitrogen atmosphere..$^{50}$ Chlorotrimethylsilane $(2.43 \mathrm{~g}, \mathbf{2 2 . 5} \mathrm{mmol})$ was added drop-wise into this solution and the mixture was kept under reflux temperature of $50{ }^{\circ} \mathrm{C}$ for $12 \mathrm{~h}$ and $36 \mathrm{~h}$ to recover chloromethylated polysulfone $2 \mathrm{a}$ (DS=30 \%, $0.89 \mathrm{~g}$ ) and $2 \mathrm{~b}$ (DS=89 \%, 0.95 g) respectively after the reaction being quenched by slowly adding the reaction mixture into ethanol. The precipitated polymers were re-dissolved in chloroform (10\% w/v solution) and re-precipitated in methanol followed by drying at $50{ }^{\circ} \mathrm{C}$ under vacuum for 12 hours. ${ }^{1} \mathrm{H}$ NMR (40o $\left.\mathrm{MHz}, \mathrm{DMF}\right) \delta(\mathrm{ppm})$ : 8.05-6.90 (aromatic backbone), $4.75\left(\mathrm{brs}, 2 \mathrm{H}, \mathrm{CH} \mathrm{Cl}_{2}\right), 1.70$ (brs, 6H, C-CH $_{3}{ }^{13} \mathrm{C}$ NMR (10o MHz, DMF) $\delta(\mathrm{ppm})$ : 118.16-162.70 (aromatic backbone), $42.58\left(\boldsymbol{C}-\mathrm{CH}_{3}\right), 41.48\left(\mathrm{CH}_{2} \mathrm{Cl}\right), 30.60$ $\left(\mathrm{C}-\mathrm{CH}_{3}\right)$. 
General procedure for azidation reaction. Synthesis of 3: A mixture of $2 \mathrm{a}(1 \mathrm{~g}, \mathrm{o} .6 \mathrm{mmol}$ of chloromethyl functionalities) and sodium azide (o.16 g, $2.43 \mathrm{mmol}$ ) was stirred in DMF (10 mL) at $6 \mathrm{o}^{\circ} \mathrm{C}$ for $24 \mathrm{~h} .{ }^{23}$ After this, the reaction mixture was centrifuged twice to separate remaining salts (excess of sodium azide and sodium chloride formed during the reaction) and the polymer was precipitated by pouring the solution drop-wise into methanol to recover azide-functionalized polysulfone $3 a$ which was then dried at $50{ }^{\circ} \mathrm{C}$ under vacuum for $12 \mathrm{~h}(0.93 \mathrm{~g})$. The same procedure was applied to $2 \mathrm{~b}(1 \mathrm{~g}, 0.61 \mathrm{mmol})$ to obtain $3 \mathrm{~b}$ (o.9o g). ${ }^{1} \mathrm{H}$ NMR (40o MHz, DMF) $\delta(\mathrm{ppm}): 8.05-6.90$ (aromatic backbone), 4.46 (brs, $2 \mathrm{H}, \mathrm{CH}_{2} \mathrm{~N}_{3}$ ), 1.70 (brs, $6 \mathrm{H}$, $\left.\mathrm{C}-\mathrm{CH}_{3}\right) .{ }^{33} \mathrm{C}$ NMR (100 MHz, DMF) $\delta(\mathrm{ppm}):$ 117.90-161.82 (aromatic backbone), $49.75\left(\mathrm{CH}_{2} \mathrm{~N}_{3}\right), 42.27\left(\mathrm{C}-\mathrm{CH}_{3}\right), 30.43\left(\mathrm{C}-\mathrm{CH}_{3}\right)$.

General Procedure for MA-CuAAC. Synthesis of 4,5,6. A solution of 3a (100 mg, $0.062 \mathrm{mmol}$ of azide functionalities), 1pentyne (I, 12.6mg, $0.19 \mathrm{mmol}), \mathrm{CuI} \cdot \mathrm{P}(\mathrm{OEt})_{3}(22 \mathrm{mg}$, $0.062 \mathrm{mmol})$ and DIPEA $(8 \mathrm{mg}, 0.062 \mathrm{mmol})$ in DMF $(5 \mathrm{~mL})$ was prepared in a glass recipient and then placed in a microwave reactor (Sairem MiniFlow 220SS) ${ }^{24}$. The maximum power of the reactor was set at $20 \mathrm{~W}$. The reaction was carried out at $120^{\circ} \mathrm{C}$ for 30 minutes under constant stirring. Afterwards, the solution was slowly added into methanol and the precipitated polymer was washed with methanol several times followed by drying under vacuum at $50^{\circ} \mathrm{C}$ for $24 \mathrm{~h}$. To extract the catalyst, a solution of the dried polymer in chloroform (10 $\mathrm{mL}$ ) and a solution of PMDETA $(150 \mu \mathrm{L})$ in water $(2 \mathrm{~mL})$ were taken in a separating funnel, shaken well and left for a short time to settle out forming two layers. The aqueous phase forming the bottom layer turned blue due to complexation of the catalyst and was removed. The recovered organic phase was then taken and the procedure was repeated until the aqueous phase was colorless. Afterwards, the retrieved organic phase was concentrated by evaporation of half of the volume of the solvent followed by its drop-wise addition into methanol to precipitate the polymer. The precipitated polymer was then dried at 50 ${ }^{\circ} \mathrm{C}$ under vacuum for 12 hours to recover 1,2,3-triazole-functionalized polysulfone $4 \mathrm{a}(85 \mathrm{mg})$. An identical procedure was used combining 3a (100 mg, $0.062 \mathrm{mmol}$ ) with 1-nonyne (II, $11.5 \mathrm{mg}, 0.093 \mathrm{mmol}$ ) and phenylacetylene (III, $9.5 \mathrm{mg}, 0.093$ $\mathrm{mmol}$ ) yielding $5 \mathrm{a}(93 \mathrm{mg})$ and $6 \mathrm{a}(88 \mathrm{mg})$ respectively as well as combining $3 \mathrm{~b}$ (10o $\mathrm{mg}$, $0.19 \mathrm{mmol})$ with 1-nonyne (II, 34.6 $\mathrm{mg}, 0.28 \mathrm{mmol}$ ) and phenylacetylene (III, $28.5 \mathrm{mg}$, $0.093 \mathrm{mmol}$ ) yielding $5 \mathrm{~b}(105 \mathrm{mg})$ and $6 \mathrm{~b}(102 \mathrm{mg})$ respectively. The CuAAC reaction between $3 \mathrm{a}(100 \mathrm{mg}, 0.062 \mathrm{mmol}$ ) and 1-pentyne (I, 12.6mg, $0.19 \mathrm{mmol}$ )/phenylacetylene (III, $9.5 \mathrm{mg}, 0.093$ $\mathrm{mmol}$ ) using conventional heating was also carried out for 20 hours using a protocol described earlier ${ }^{51,52}$ yielding $4 \mathrm{a}$ (57 $\mathrm{mg})$ and $6 \mathrm{a}(51 \mathrm{mg})$ respectively.

4: ${ }^{1} \mathrm{H}$ NMR (40o MHz, DMF) $\delta(\mathrm{ppm}):$ 8.05-6.90 (aromatic backbone), $7.75(\mathrm{~s}, 1 \mathrm{H}, \mathrm{CN}=\mathrm{CH}), 5.58\left(\mathrm{brs}, 2 \mathrm{H}, \mathrm{C} \boldsymbol{H}_{2} \mathrm{~N}\right), 2.46(\mathrm{t}$, $2 \mathrm{H}, \mathrm{CNCH}_{2} \mathrm{CH}_{2} \mathrm{CH}_{3}$ ), 1.70 (brs, $\left.6 \mathrm{H}, \mathrm{C}-\mathrm{CH}_{3}\right), 1.49\left(\mathrm{brm}, 2 \mathrm{H}, \mathrm{CNCH}_{2} \mathrm{CH}_{2} \mathrm{CH}_{3}\right)$, o.8o (t, $\left.3 \mathrm{H}, \mathrm{CNCH}_{2} \mathrm{CH}_{2} \mathrm{CH}_{3}\right) .{ }^{13} \mathrm{C} \mathrm{NMR}(100 \mathrm{MHz}$, DMF) $\delta(\mathrm{ppm})$ : 118.15-162.65 (aromatic backbone), $148.19(\mathrm{CN}=\mathrm{CH}), 122.41(\mathrm{CN}=\mathrm{CH}), 48.66\left(\mathrm{CH}_{2} \mathrm{~N}\right), 42.53\left(\boldsymbol{C}-\mathrm{CH}_{3}\right), 30.70(\mathrm{C}-$ $\left.\mathrm{CH}_{3}\right), 27.58\left(\mathrm{CNCH}_{2} \mathrm{CH}_{2} \mathrm{CH}_{3}\right), 22.84\left(\mathrm{CNCH}_{2} \mathrm{CH}_{2} \mathrm{CH}_{3}\right), 13.56\left(\mathrm{CNCH}_{2} \mathrm{CH}_{2} \mathrm{CH}_{3}\right)$.

5: ${ }^{1} \mathrm{H}$ NMR (40o MHz, DMF) $\delta(\mathrm{ppm}): 8.05-6.90$ (aromatic backbone), $7.78(\mathrm{~s}, 1 \mathrm{H}, \mathrm{CN}=\mathrm{CH}), 5.58\left(\mathrm{brs}, 2 \mathrm{H}, \mathrm{CH}_{2} \mathrm{~N}\right), 2.52$ (t, $2 \mathrm{H}, \mathrm{CNCH}_{2} \mathrm{CH}_{2} \mathrm{CH}_{2} \mathrm{CH}_{2} \mathrm{CH}_{2} \mathrm{CH}_{2} \mathrm{CH}_{3}$ ), 1.70 (brs, $6 \mathrm{H}, \mathrm{C}-\mathrm{CH}_{3}$ ), 1.52 (brs, $2 \mathrm{H}, \mathrm{CNCH}_{2} \mathrm{CH}_{2} \mathrm{CH}_{2} \mathrm{CH}_{2} \mathrm{CH}_{2} \mathrm{CH}_{2} \mathrm{CH}_{3}$ ), 1.23 (brs, $8 \mathrm{H}$, $\mathrm{CNCH}_{2} \mathrm{CH}_{2} \mathrm{CH}_{2} \mathrm{CH}_{2} \mathrm{CH}_{2} \mathrm{CH}_{2} \mathrm{CH}_{3}$ ), o.8o (t, ${ }_{3} \mathrm{H}, \mathrm{CNCH}_{2} \mathrm{CH}_{2} \mathrm{CH}_{2} \mathrm{CH}_{2} \mathrm{CH}_{2} \mathrm{CH}_{2} \mathrm{CH}_{3}$ ). ${ }^{13} \mathrm{C}$ NMR (100 MHz, DMF) $\delta(\mathrm{ppm}): 118.15-$ 162.65 (aromatic backbone), $148.19(\mathrm{CN}=\mathrm{CH}), 122.35(\mathrm{CN}=\mathrm{CH}), 48.64\left(\mathrm{CH}_{2} \mathrm{~N}\right), 42.52\left(\mathrm{C}_{-} \mathrm{CH}_{3}\right), 30.70\left(\mathrm{C}-\mathrm{CH}_{3}\right), 29.15-31.94$ $\left(\mathrm{CNCH}_{2} \mathrm{CH}_{2} \mathrm{CH}_{2} \mathrm{CH}_{2} \mathrm{CH}_{2} \mathrm{CH}_{2} \mathrm{CH}_{3}\right)$, $25.57\left(\mathrm{CNCH}_{2} \mathrm{CH}_{2} \mathrm{CH}_{2} \mathrm{CH}_{2} \mathrm{CH}_{2} \mathrm{CH}_{2} \mathrm{CH}_{3}\right)$, $22.73\left(\mathrm{CNCH}_{2} \mathrm{CH}_{2} \mathrm{CH}_{2} \mathrm{CH}_{2} \mathrm{CH}_{2} \mathrm{CH}_{2} \mathrm{CH}_{3}\right)$, 13.96 $\left(\mathrm{CN} \mathrm{CH}_{2} \mathrm{CH}_{2} \mathrm{CH}_{2} \mathrm{CH}_{2} \mathrm{CH}_{2} \mathrm{CH}_{2} \mathrm{CH}_{3}\right.$ ).

6: ' ${ }^{\mathrm{H}} \mathrm{NMR}$ (400 MHz, DMF) $\delta(\mathrm{ppm})$ : 8.05-6.9o (aromatic backbone + phenyl substituent of 1,4-substituted triazole ring), $8.49(\mathrm{~s}, 1 \mathrm{H}, \mathrm{CN}=\mathrm{CH}), 5.69$ (brs, $\left.2 \mathrm{H}, \mathrm{CH}_{2} \mathrm{~N}\right), 1.7 \mathrm{O}$ (brs, 6H, C-CH ${ }_{3}$ ). ${ }^{13} \mathrm{C} \mathrm{NMR}(100 \mathrm{MHz}, \mathrm{DMF}) \delta(\mathrm{ppm}): 118.15-162.65$ (aromatic backbone + phenyl substituent of 1,4-substituted triazole ring), $148.21(C \mathrm{~N}=\mathrm{CH}), 121.77(\mathrm{CN}=\boldsymbol{C H}), 48.96\left(\boldsymbol{C} \mathrm{H}_{2} \mathrm{~N}\right), 42.53(\boldsymbol{C}$ $\left.\mathrm{CH}_{3}\right), 30.69\left(\mathrm{C}-\mathrm{CH}_{3}\right)$.

\section{Results and Discussion}

Synthesis of 1,2,3-triazole functionalized polysulfones and their characterization

1,2,3-triazole functionalized polysulfone was synthesized by sequential chemical modifications of the initial polymer followed by microwave-assisted Copper-catalyzed Azide Alkyne Cycloaddition (CuAAC) reaction (Scheme 1). Firstly, chloromethylation of polysulfone 1 was carried out in $\mathrm{CHCl}_{3}$ by using chlorotrimethylsilane, $\mathrm{p}$-formaldehyde and tin tetrachloride as previously described53. The degree of substitution (DS) of the resulting chloromethylated polymer 2 was calculated from the ratio of the $\mathrm{CH}_{2} \mathrm{Cl}$ proton signal to that of the methyl proton signal in the ${ }^{1} \mathrm{H}$-NMR spectrum (Table 1). After reaction at $50{ }^{\circ} \mathrm{C}$ for 12 and 36 hours, the degrees of substitution were 30 and $89 \%$ respectively, considering one functional group per repeating unit. Afterwards, 2 was modified out by reacting it with sodium azide in DMF at $45^{\circ} \mathrm{C}$ for 48 hours to afford azide- 
functionalized polysulfone 3. The quantitative transformation of chloromethylated sites into azidomethylated sites was confirmed in the ${ }^{1} \mathrm{H}-\mathrm{NMR}$ by the total disappearance of the signal of the methylene protons of $\mathrm{CH}_{2} \mathrm{Cl}$ at $4.75 \mathrm{Ppm}$ and the appearance of a resonance at $4.46 \mathrm{ppm}$ characteristic of $\mathrm{CH}_{2} \mathrm{~N}_{3}$, as well as by a change in the chemical shift of aromatic $\beta$ hydrogen, with respect to the methylated-functional group, from $7.65 \mathrm{ppm}$ to $7.48 \mathrm{ppm}$ (figure 1 ). The composition of the modified polymers was determined by elemental analysis through combustion and pyrolysis processes. Table 1 presents the experimental values determined by the analysis, which are fully consistent with those deduced from the DS.

The azided-polysulfones $3 \mathrm{a}$ and $3 \mathrm{~b}$ were used as precursors for the preparation of 1,2,3-triazole functionalized polysulfones. Microwave assisted chemistry is completely dependent on the ability of the components of the reaction mixture to absorb microwave energy and transform it into heat. The heating characteristics of the components in turn depend on their dielectric properties ${ }^{4}$. In particular, the reaction medium plays a very significant role in efficient absorption of microwaves and rapid heating of the system. A system with high polarity is therefore likely to encourage instant sufficient heating by microwaves. In this regard, DMF exhibits satisfactory microwave absorption while also being a good solvent for azidedpolysulfone and thus it was chosen as the reaction medium for MA-CuAAC. Initially, a limpid solution of the azided polymer, alkyne (I: 1-pentyne or II: 1-nonyne or III: 1-phenylacetylene, CuIP(OEt) 3 and DiPEA was prepared in DMF in a closed quartz recipient followed by exposure to microwave energy in the reactor for 30 minutes. The temperature of the system was controlled at $120^{\circ} \mathrm{C}$ during the course of the reaction. The microwave reactor utilized in the work constantly provided the data concerning the absorbed as well as the reflected microwave power by the reaction system. All the reaction mixtures absorbed power up to 13-14 W to maintain the temperature while the maximum power was set at $20 \mathrm{~W}$. After precipitation and removal of the catalyst, the extent of CuAAC reaction between za and I or II or III resulting in 4a or 5a or 6a respectively, was confirmed to be complete from the appearance of 1,2,3-triazole proton signal at $7.75 \mathrm{ppm}, 7.78 \mathrm{ppm}$ and $8.49 \mathrm{ppm}$ for $4 \mathrm{a}$, 5a and 6a respectively, the quantitative shift of the peak at $4.46 \mathrm{ppm}$ for the methylene protons neighboring the azide of 3 a to $5.58 \mathrm{ppm}, 5.58 \mathrm{ppm}$ and $5.69 \mathrm{ppm}$ for the methylene protons neighboring $\mathrm{N}-1$ position of the 1,2,3-triazole group of $4 \mathrm{a}, 5 \mathrm{a}$ and $6 \mathrm{a}$ respectively, and the change in position of the peak at $7.52 \mathrm{ppm}$ corresponding to aromatic $\beta$-hydrogen in $3 \mathrm{a}$ towards lower chemical shift, where it is superimposed on other aromatic proton peaks present between 7.27-7.37 ppm for 4a, 5a and 6a respectively (Figure 1). In addition, new peaks corresponding to the propyl, heptyl and phenyl moieties of the 1,4-substituted 1,2,3-triazole groups of 4a, 5a and 6a respectively are clearly observed with matching integration ratios (all the labels are displayed in figure 1). ). It is important to note that all the spectra recorded in this work were obtained for samples dissolved in deuterated-DMF instead of the commonly used $\mathrm{CDCl}_{3}$ since the former allowed very clear segregation of peaks corresponding to aromatic and 1,2,3-triazole protons which thus facilitated collection of evidence for the chemical transformations occurring at each step. Furthermore, in the ATR-FTIR a band observed previously at $2093 \mathrm{~cm}^{-1}$ for the azide group of $3 \mathrm{a}$ is absent in the spectra of $4 \mathrm{a}, 5 \mathrm{a}$ and $6 \mathrm{a}$ (Figure 2), which is also consistent with completion of the CuAAC reaction. High purity of the clicked polymers (4a, 5a and 6a) was ascertained by DOSY-NMR which, as a spectroscopic chromatography tool, helps in separating different species present in a mixture based on their diffusion coefficients, since each species exhibits a distinct diffusion coefficient, depending on its size and shape. For instance, the DOSY-NMR spectrum of 5 a (figure 3 ) shows no species other than the clicked polymer itself and thus affirms its high purity. Also, we carried out the CuAAC reaction on azided polysulfone by using a conventional method so as to compare with the results obtained with the microwave-assisted route. The conventional method requires not only complicated preparation steps such as multiple freeze/thaw cycles and inert atmosphere throughout the reaction, in order to avoid any unwanted side reactions but also needs up to 20 hours for the completion of the reaction with lower yield ( $43 \%$ of $5 \mathrm{a}$ and $40 \%$ of $6 \mathrm{a}$ ) of the final product. In order to validate the efficiency of MA-CuAAC for the synthesis of highly functionalized polymers, the same procedure was carried out on $3 \mathrm{~b}$ (with DS=0.89) and 1-nonyne or 1 -phenylacetylene leading to formation of $5 \mathrm{~b}$ and $6 \mathrm{~b}$ respectively with similar rapidity and high yields. The ATR-FTIR spectra of $5 \mathrm{~b}$ and $6 \mathrm{~b}$ confirm the completion of the CuAAC reaction through the disappearance of the band observed previously at $2093 \mathrm{~cm}^{-1}$ for the azide group of $3 \mathrm{~b}$ (figure S1 of supplementary information). Thus, MA-CuAAC provides a very facile route to polymers bearing the 1,2,3-triazole functionality with a range of alkyl and aryl pendant structures.

The solubility behavior of azided- and 1,2,3-triazole-functionalized polysulfones remains similar to non-modified polysulfone (Table 2). All these polymers are soluble in polar aprotic solvents such as DMF, dimethylsulfoxide (DMSO) and dimethylacetamide (DMAc) while insoluble in polar protic solvents such as water, methanol (MeOH) and ethanol (EtOH) as well as non-polar solvents such as hexane, toluene with an exception of being soluble in chloroform;

The glass transition temperatures $\left(T_{g}\right)$ of azided precursors $3(a, b)$ and their 1,2,3-triazole derivatives 4-6 (a,b) were determined using Differential Scanning Calorimetry (DSC). PSU is an amorphous polymer with $\mathrm{T}_{\mathrm{g}}$ of $188^{\circ} \mathrm{C}$. Azidation of PSU results in slight decrease in its $T_{g}\left(T_{g}=170{ }^{\circ} \mathrm{C}\right.$ for $3 a$ and $T_{g}=151{ }^{\circ} \mathrm{C}$ for $3 \mathrm{~b}$, Table 2 ) as previously reported. $5^{2}$ Conversely, the $T_{g}$ of 1,2,3-triazole functionalized polysulfone is considerably impacted by the nature of the substituent on the triazole group according to: heptyl $<$ propyl $<$ phenyl. The higher $T_{\mathrm{g}}$ of the phenyl substituted 1,2,3-triazole-polymer is likely to be due to its bulkier nature, imparting rigidity and resonance stabilization to the polymer structure, in comparison to alkyl pendant 
groups. ${ }^{55,56}$ Moreover, an increase in the chain length of the alkyl pendant group results in a decrease in the $\mathrm{T}_{\mathrm{g}}$ of the polymer owing to decrease in intermolecular coupling $\left(\mathrm{T}_{\mathrm{g}}=147^{\circ} \mathrm{C}\right.$ for $4 \mathrm{a}$ and $\mathrm{T}_{\mathrm{g}}=138^{\circ} \mathrm{C}$ for $\left.5 \mathrm{a}\right) .55$ Similar trends of decrease in $\mathrm{T}_{\mathrm{g}}$ with increasing chain length of the pendant alkyl group have been reported for poly (alkylmethacrylates) 57 and alkyl substituted poly $\mathrm{N}$-vinylimidazolium ${ }^{48}$. Interestingly, the impact of the degree of 1,2,3-triazole functionalization on the $\mathrm{T}_{\mathrm{g}}$ of the material also depends on the chemical nature of the substituent on the heterocycle. While increase in the degree of 4 -heptyl-1,2,3triazole functionalization results in a decrease in $T_{g}\left(T_{g}=138^{\circ} \mathrm{C}\right.$ for $5 \mathrm{a}$ and $T_{g}=115^{\circ} \mathrm{C}$ for 5 b), 4-phenyl-1,2,3-triazole functionalization does not exhibit such sharp decrease $\left(T_{g}=182{ }^{\circ} \mathrm{C}\right.$ for $6 a$ and $T_{g}=176{ }^{\circ} \mathrm{C}$ for $\left.6 \mathrm{~b}\right)$. These results clearly underline the impact of pendant structure-stiffness/flexibility on the activation of the backbone segmental motion and thus influence on the $\mathrm{T}_{\mathrm{g}}$ of the 1,2,3-triazole-functionalized-polymer.

The thermal stability of functionalized polysulfones was investigated using thermogravimetric analysis (TGA) coupled with mass spectroscopy to analyze the decomposition products generated at different steps during heating. Although the mass spectrum obtained during the course of the analysis was complex, it provided substantial information to understand the mechanism of thermal degradation of the modified polymers. Unmodified polysulfone starts decomposing only above $500{ }^{\circ} \mathrm{C}$. Its functionalization by chlormethylation and azidation results in reduced thermal stability although conversion of azided sites into 1,2,3-triazole groups increases the temperature at which the polymer decomposes (figure 4, Table 2). Nevertheless, all the functionalized polysulfones remain thermally stable at least up to $200{ }^{\circ} \mathrm{C}$. Two main steps of mass loss were observed for all the functionalized polymers. Azided-polysulfone exhibits a first mass loss at $210-230{ }^{\circ} \mathrm{C}$ (depending on the degree of functionalization) due to expulsion of nitrogen gas evidenced by a strong ion current peak for the species with $\mathrm{m} / \mathrm{z}=28$ (figure 4) leading to transformation of azided sites into nitrene sites, analogous to the thermal behavior of glycidyl azide. $5^{8}$ The second major weight loss observed above $340^{\circ} \mathrm{C}$ is mainly due to the decomposition of the polymer backbone resulting in evolution of sulfur dioxide $(\mathrm{m} / \mathrm{z}=64)$, phenol $(\mathrm{m} / \mathrm{z}=94)$, toluene $(\mathrm{m} / \mathrm{z}=91)$, benzene $(\mathrm{m} / \mathrm{z}=78)$ and methane $(\mathrm{m} / \mathrm{z}=16)$, in agreement with the analysis reported by Gabor et al. on the thermal decomposition of different chemically functionalized polysulfones (such as brominated, bromo-methylated, nitrated, carboxylated). 59 All the 1,2,3-triazole functionalized polymers 4-6 (a,b) undergo thermal degradation in two consecutive steps while the onset temperature depends on the nature of the substituent on the 1,2,3-triazole functionality and the effect is more clearly visible for polymers with higher degree of functionalization (figure 4; TGA thermograms of polymers with $30 \%$ degree of functionalization not shown). Generally, 1,2,3-triazoles undergo decomposition of the triazole ring at elevated temperatures $\left(300-600^{\circ} \mathrm{C}\right.$ ) forming a carbene and eliminating nitrogen gas. ${ }^{60} 6 \mathrm{~b}$ begins to decompose at $370^{\circ} \mathrm{C}$ with elimination of nitrogen gas $(\mathrm{m} / \mathrm{z}=28)$ which can be attributed to the initial decomposition of 1,2,3-triazole ring while for $5 \mathrm{~b}$ thermal decomposition begins around $300{ }^{\circ} \mathrm{C}$ with elimination of nitrogen gas and alkyl fragments $(\mathrm{m} / \mathrm{z}=43,57)$ signifying initial decomposition of $1,2,3$-triazole ring along with its alkyl substituent group. The decomposition of the 1,2,3-triazole ring is quickly followed by decomposition of the polymer backbone for both $5 \mathrm{~b}$ and $6 \mathrm{~b}$ generating similar by-products observed as in the case of the azided polymer. The better thermal stability of $6 \mathrm{~b}$ can be attributed to the steric shielding provided by the phenyl group to the 1,2,3-triazole ring. Similar impact of alkyl and phenyl substituents on the thermal stability of poly (alkylphenylpropiolate) has been reported. ${ }^{61}$

Phosphoric acid doped 1,2,3-triazole functionalized polysulfone membranes

The polymers with high degree of 1,2,3-triazole functionality bearing heptyl (5b) and phenyl (6b) triazole ring substituents were cast into membranes using DMF as solvent. Membrane thickness, after removal of solvent and annealing, was $30 \mu \mathrm{m}$. Membranes were immersed in $14.6 \mathrm{M}$ phosphoric acid solution ( $85 \mathrm{wt} \%$ in water) at ambient temperature and at $110^{\circ} \mathrm{C}$ for different time periods (depending on the type of the membrane) until saturation in acid uptake was achieved. The Acid Doping Levels (ADL, number of phosphoric acid molecules per repeat unit of the polymer) of the doped membranes were determined by ion chromatography (Table 3). When acid doping was carried out at room temperature, the acid doping level for $5 \mathrm{~b}$ membrane was observed to reach a maximum value of 2 after 72 hours, while almost no acid uptake occurred for membrane $6 \mathrm{~b}$ under these conditions. This behavior of $6 \mathrm{~b}$ was unexpected, and can be attributable to high rigidity/steric hindrance imparted by phenyl pendant ring-structure to the polymer structure inhibiting any interactions of the triazole ring with phosphoric acid. At $110{ }^{\circ} \mathrm{C}$, the ADL of $5 \mathrm{~b}$ reached at its maximum of 4.9 molecules $\mathrm{H}_{3} \mathrm{PO}_{4}$ per polymer repeat unit after only 1 hour. Uptake of phosphoric acid by $6 \mathrm{~b}$ membrane was slower, but nevertheless achieved an ADL of 5.0 after 48 hours immersion. Since the membranes were immersed in an aqueous solution of phosphoric acid, it's equally interesting to evaluate the contribution of phosphoric acid and water in the total uptake. Thus, in terms of acid and water uptake (AU\% and WU\% respectively) for these doped membranes swollen at $110{ }^{\circ} \mathrm{C}$, $5 \mathrm{~b}$ exhibited an uptake of $70 \%$ of phosphoric acid and $12 \%$ of water while $6 \mathrm{~b}$ exhibited an uptake of $74 \%$ of phosphoric acid and $18 \%$ of water. The two contributions of the acid and water uptakes roughly correspond to the weight percent of water and phosphoric acid present in the $14.6 \mathrm{M}$ aqueous solution of phosphoric acid though $6 \mathrm{~b}$ seems to be slightly more hydrophilic than $5 \mathrm{~b}$. Moreover, membrane $6 \mathrm{~b}$ exhibits much lesser area swelling in comparison to than $5 \mathrm{~b}$ for very similar ADL, while volume swelling is the same for both (Table 
3). These results clearly underline significant impact of nature of 1,2,3-triazole substituent on acid uptake kinetics of the final membrane.

The proton conductivities obtained with 1,2,3-triazole functionalized membranes ( $5 \mathrm{~b}$ and $6 \mathrm{~b}$ ) were compared to that of obtained with polybenzimidazole (PBI). A $10 \mathrm{wt} \%$ solution of PBI in dimethylacetamide was prepared in a closed vessel to cast a membrane with initial thickness of $52 \mu \mathrm{m}$ which was then dipped in $14.6 \mathrm{M}$ phosphoric acid solution at $25{ }^{\circ} \mathrm{C}$ for 24 hours to obtain an ADL of 6.5. The dependence of the proton conductivity of phosphoric acid doped $5 \mathrm{~b}$ and $6 \mathrm{~b}$ on temperature is shown in Figure 5, where it is compared with that of phosphoric acid doped polybenzimidazole (PBI). The conductivity of both the acid-doped 1,2,3-triazole functionalized membranes increases with increasing temperature ( $\sigma$ at $110{ }^{\circ} \mathrm{C}$ of $5 \mathrm{~b}=29 \mathrm{mS} / \mathrm{cm}$ and of $6 \mathrm{~b}=22 \mathrm{mS} / \mathrm{cm}$ ). The higher conductivity of $5 \mathrm{~b}$ than $6 \mathrm{~b}$ could be related to the lower $\mathrm{T}_{\mathrm{g}}$ of the former allowing improved segmental motion and thus improved conductivity. The ADL and thus the proton conductivity of acid doped 1,2,3-triazole functionalized polymers is lower than that of $\mathrm{H}_{3} \mathrm{PO}_{4} / \mathrm{PBI}$. However, PBI contains two imidazole groups per repeat unit while $5 \mathrm{~b}$ and $6 \mathrm{~b}$ possess only 0.89 1,2,3-triazole moiety per repeating unit in this case which results in higher acid uptake and thus proton conductivity of the former.

The mechanical properties of the membranes of $5 \mathrm{~b}$ and $6 \mathrm{~b}$ before and after doping with phosphoric acid were investigated (Table 3$) .6 b$ presents higher elastic modulus $\left(E_{\bmod }\right)$ than $5 \mathrm{~b}\left(E_{\bmod }\right.$ of $5 \mathrm{~b}=1438 \mathrm{MPa}$ and of $\left.6 \mathrm{~b}=1622 \mathrm{MPa}\right)$ which can be linked to the rigidity imparted by phenyl substituent of the 1,2,3-triazole ring to the polymer structure. After doping with phosphoric acid, as expected, $6 \mathrm{~b}$ continue to present relatively higher elastic modulus and lower elongation at break (El) in comparison to $5 \mathrm{~b}$ ( $\mathrm{E}_{\mathrm{mod}}$ and $\mathrm{El}$ of $6 \mathrm{~b}-5.0-\mathrm{H}_{3} \mathrm{PO}_{4}=349.0 \mathrm{MPa}$ and $11.3 \%$ respectively; $\mathrm{E}_{\bmod }$ and $\mathrm{El}$ of $5 \mathrm{~b}-4.9-\mathrm{H}_{3} \mathrm{PO}=332.7 \mathrm{MPa}$ and $19.3 \%$ respectively) owing to lower plasticization of the doped polymer matrix of the former due to it its structural rigidity (Table 3 ). Based on all the results, it can be inferred that by increasing the degree of functionalization to multiple 1,2,3-triazole groups per polymer repeating unit (through increase in chloro-methylation degree up to 2 functional groups per repeat unit) as well as by careful choice of the pendant ring substituent, the functional properties can be modulated according to the requirements of the application.

\section{Conclusion}

Application of microwave heating to macromolecular synthesis and modification holds great promise for developing straightforward, fast and high-yielding routes to high performance functional materials. We have successfully exemplified this through the synthesis of 1,2,3-triazole functionalized polysulfones bearing various alkyl and aryl ring substituents using microwave-assisted CuAAC chemistry. The degree of 1,2,3-triazole functionalization of the polymer and chemical nature of the ring substituent play critical roles in defining the final properties (thermal, mechanical, proton conduction) of the functionalized polymer. Polysulfone functionalized with 4-phenyl-1,2,3-triazole is characterized by higher $T_{g}$, $T_{d}$ and elastic modulus than those with 4-propyl-1,2,3-triazole and 4-heptyl-1,2,3-triazole functionalizations. However, the proton conductivity of phosphoric acid doped polysulfone bearing 4-heptyl-1,2,3-triazole is higher than that bearing 4-phenyl-1,2,3triazole due to lower $\mathrm{T}_{\mathrm{g}}$ and higher chain mobility of the former. It is concluded that by carefully adjusting parameters such as degree of functionalization and ring substituents of 1,2,3-triazole functionality, properties and thus performance required from the material for a desired application can be achieved.

Acknowledgement

Funding from the European Research Council under the European Union's Seventh Framework Programme (FP/2007-2013) / ERC Grant Agreement n. 306682 is acknowledged. 


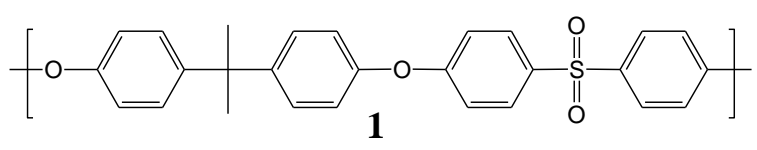

$\mathrm{SnCl}_{4}$

$\left(\mathrm{CH}_{3}\right)_{3} \mathrm{SiCl} \quad \mathrm{CHCl}_{3}, 45^{\circ} \mathrm{C}$

Paraformaldehyde

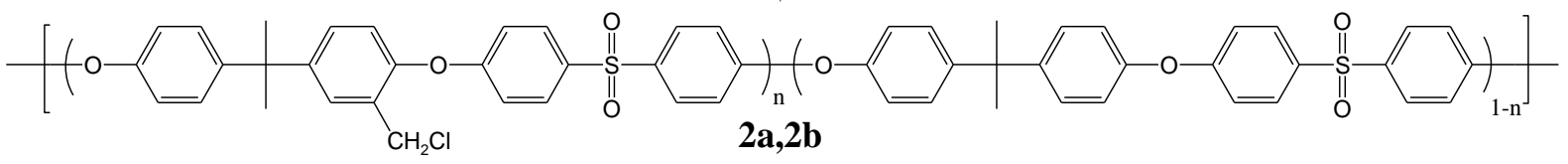

\begin{tabular}{l|l}
$\mathrm{NaN}_{3}$ & $\mathrm{DMF}, 60^{\circ} \mathrm{C}$
\end{tabular}

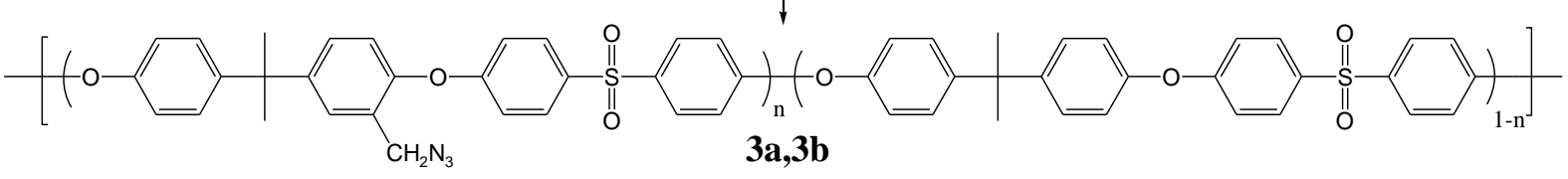

\begin{tabular}{lr|l} 
I: $\mathrm{HCC}\left(\mathrm{CH}_{2}\right)_{2} \mathrm{CH}_{3}$ & & \\
II: $\mathrm{HCC}\left(\mathrm{CH}_{2}\right)_{6} \mathrm{CH}_{3}$ & I/II/III & $20 \mathrm{~W}$ \\
III: $\mathrm{HCCC}_{6} \mathrm{H}_{5}$ & CuIP(OEt $)_{3}$ & DMF, $120^{\circ} \mathrm{C}$
\end{tabular}
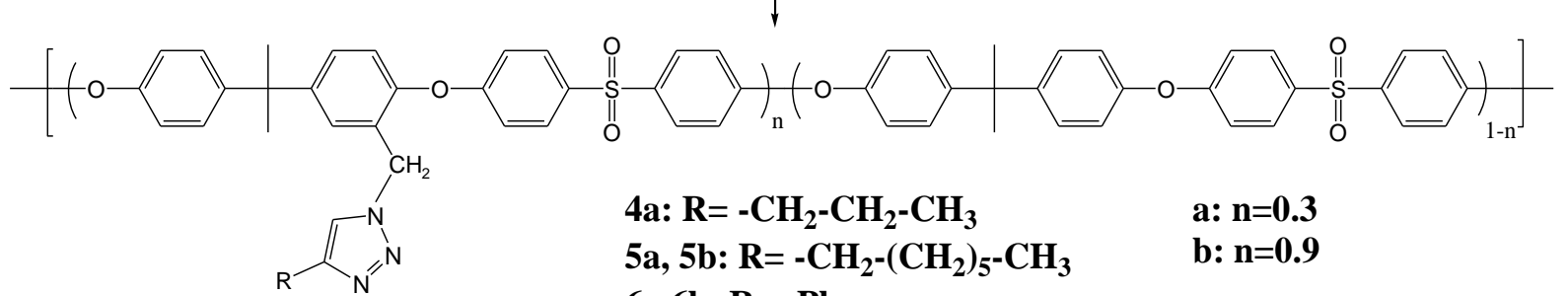

6a,6b: $R=-P h$

Scheme 1. Synthesis of 1,2,3-triazole functionalized polysulfones 4-6. 


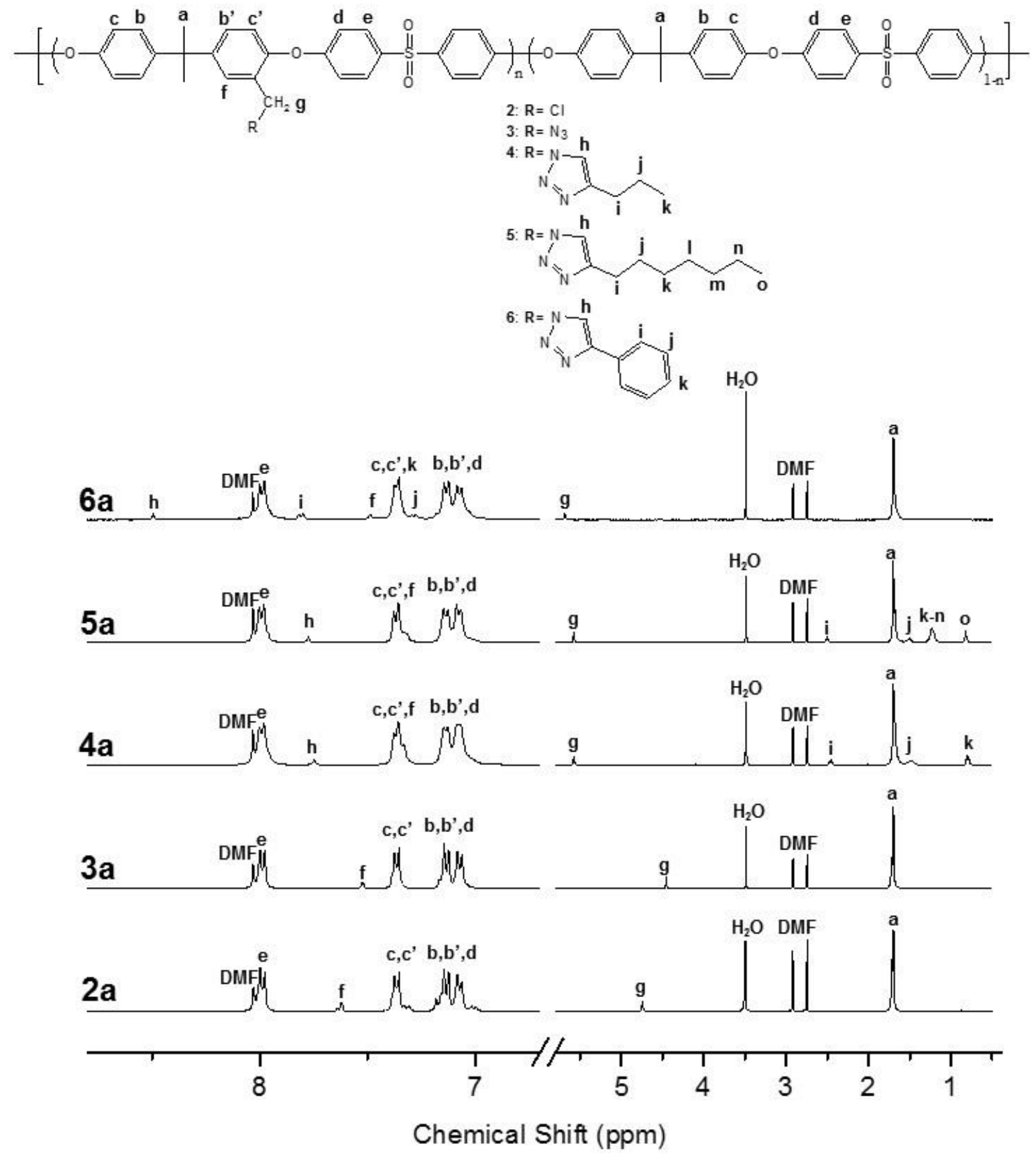

Figure 1. ${ }^{1} \mathrm{H}$ NMR (DMF, $400 \mathrm{MHz}, 25^{\circ} \mathrm{C}$ ) of chloromethyl-functionalized polysulfone $\mathbf{2 a}$, azide-functionalized polysulfone $3 \mathbf{a}$ and 1,2,3-triazole-functionalized polysulfones $\mathbf{4 a - 6 a . ~}$ 


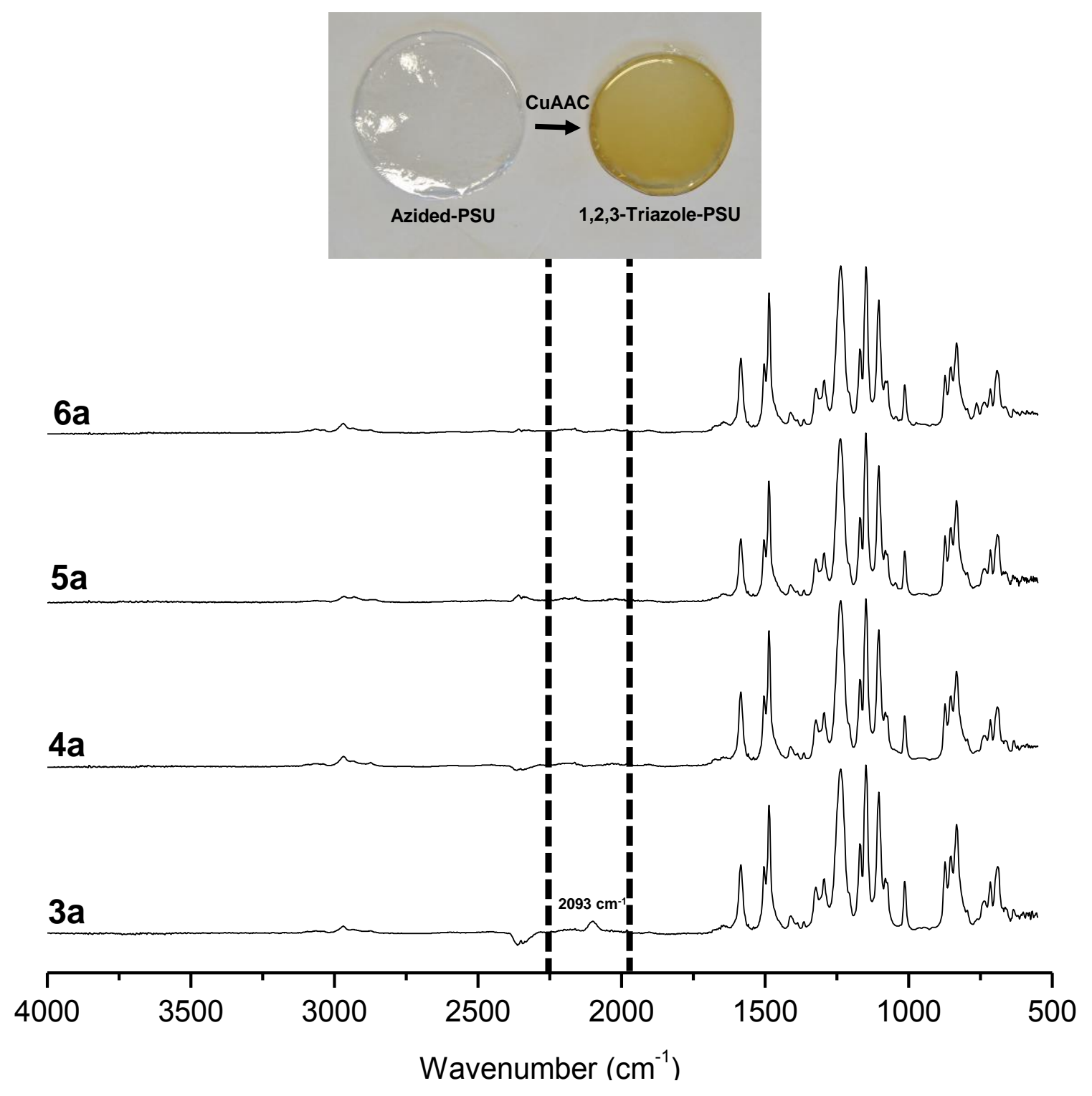

Figure 2. FTIR-ATR spectra of azide-functionalized polysulfone za and 1,2,3-triazole-functionalized polysulfones 4 a-6a, with an inset image of the polymer before and after $\mathrm{CuAAC}$ reaction. 


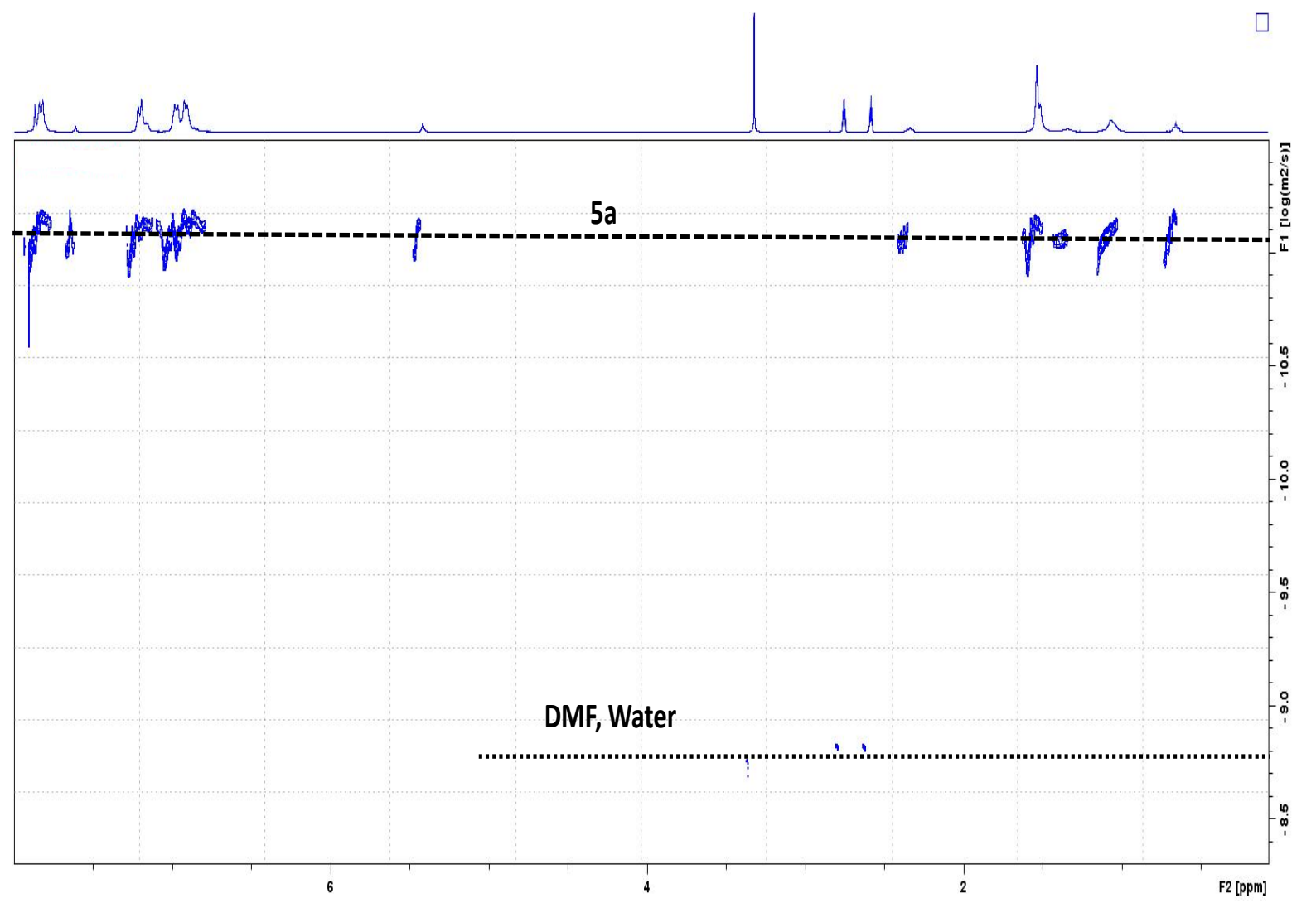

Figure 3. HR-DOSY spectrum of $5 \mathbf{5}$ in DMF, with the normal ${ }^{~} \mathrm{H}$ spectrum (top) and diffusion coefficients on the y-axis (side). 


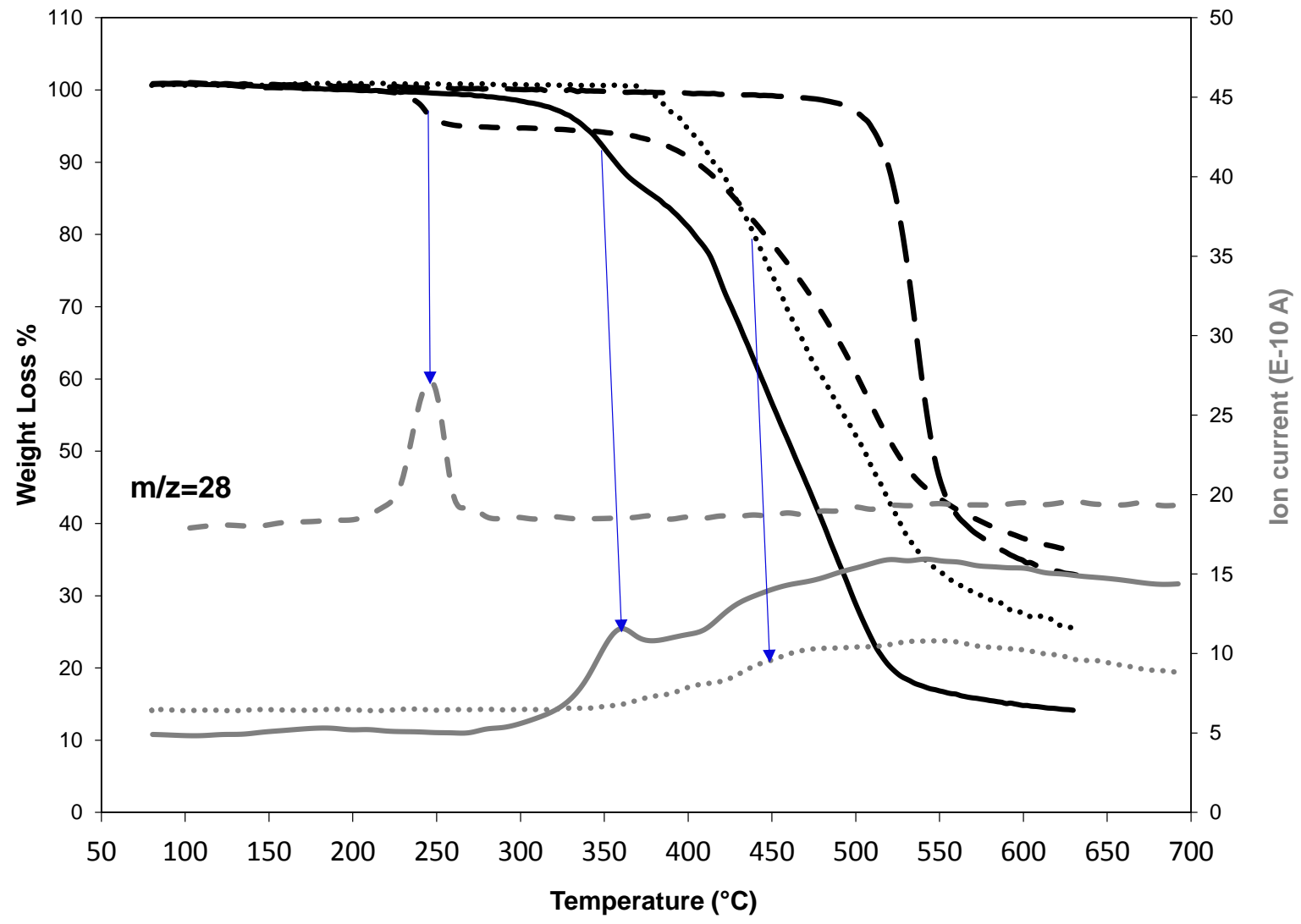

Figure 4. TGA and ion current traces for species with $\mathrm{m} / \mathrm{z}=\mathbf{2 8}$ of non-modified PSU 1 (long-dash line), azide-functionalized polysulfone $\mathbf{3 b}$ (short-dash line) and 1,2,3-triazole-functionalized polysulfones with pendant substituent i.e. $\mathbf{5} \mathbf{b}$ (solid line) and $\mathbf{6 b}$ (dotted line). 


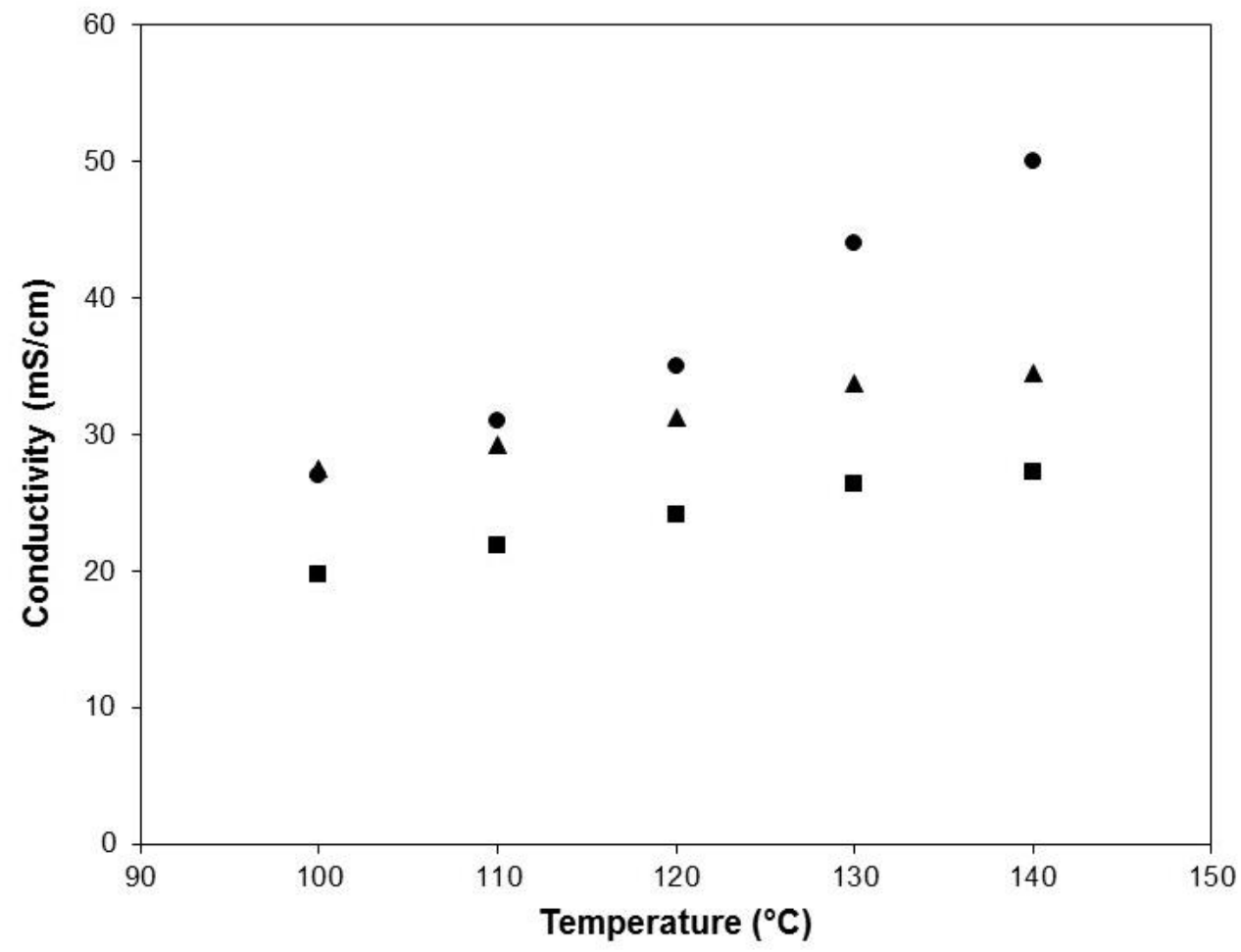

Figure 5. Conductivity of 1,2,3-triazole-functionalized polysulfones with different pendant structures $\mathbf{5 b}$ (ADL: 4.9; solid triangle) and 6b (ADL: 5.0; solid square) and of PBI (ADL: 6.5; solid circle) as a function of temperature in a closed conductivity cell under dry condition. 
Table 1. Degree of substitution (DS) and elemental analysis of azide-functionalized polysulfone 3 and 1,2,3-triazole-functionalized polysulfones 4-6.

\begin{tabular}{|c|c|c|c|c|c|c|c|c|c|c|c|}
\hline \multirow{3}{*}{$\begin{array}{l}\text { Sample } \\
\text { code }\end{array}$} & \multirow{3}{*}{$\begin{array}{l}D^{*} \\
(\%)\end{array}$} & \multicolumn{10}{|c|}{ Elemental Analysis } \\
\hline & & \multicolumn{2}{|l|}{$\mathrm{C} \%$} & \multicolumn{2}{|l|}{ H\% } & \multicolumn{2}{|l|}{ O\% } & \multicolumn{2}{|l|}{ S\% } & \multicolumn{2}{|l|}{ N\% } \\
\hline & & Theo & Exp. & Theo & Exp. & Theo. & Exp. & Theo. & Exp. & Theo. & Exp. \\
\hline 1 & o & 72.55 & 72.71 & 5.12 & 5.98 & 14.88 & $\mathrm{n} / \mathrm{a}$ & $7 \cdot 44$ & $7 \cdot 92$ & o & o \\
\hline $3 a$ & 30 & 70.64 & 68.89 & 5.06 & 4.32 & $14 \cdot 32$ & 14.18 & 7.16 & 6.98 & 2.82 & 2.73 \\
\hline $3 \mathbf{b}$ & 89 & 67.24 & 64.89 & 4.95 & 3.83 & 13.34 & 13.67 & 6.67 & 6.41 & $7 \cdot 79$ & 7.85 \\
\hline $4 a$ & 30 & 71.27 & 68.55 & 5.26 & 4.61 & 13.82 & 14.06 & 6.91 & 6.73 & 2.72 & 2.59 \\
\hline $5^{a}$ & 30 & 71.78 & 69.77 & 5.58 & 4.65 & 13.30 & 12.27 & 6.66 & 6.06 & 2.65 & 3.10 \\
\hline $5^{b}$ & 89 & 70.95 & 68.40 & 6.44 & 5.05 & 10.84 & 10.61 & $5 \cdot 42$ & 5.01 & 6.33 & 6.09 \\
\hline $6 a$ & 30 & 72.02 & $\mathrm{n} / \mathrm{a}$ & 5.02 & $\mathrm{n} / \mathrm{a}$ & 13.52 & $\mathrm{n} / \mathrm{a}$ & 6.76 & $\mathrm{n} / \mathrm{a}$ & 2.66 & $\mathrm{n} / \mathrm{a}$ \\
\hline 6b & 89 & 71.52 & 69.48 & 5.10 & 4.31 & 11.22 & 12.06 & 5.61 & 6.52 & 6.55 & 6.44 \\
\hline
\end{tabular}

${ }^{*}$ Calculated from ${ }^{~} \mathrm{H}-\mathrm{NMR}$ spectrum; Theoretical values (Theo.) were calculated based on DS values; Experimental values (Exp.) were determined by combustion and pyrolysis analysis 
Table 2. Thermal and solubility properties of azide-functionalized polysulfone 3 and 1,2,3-triazole-functionalized polysulfones 4-6.

\begin{tabular}{|c|c|c|c|c|c|c|c|}
\hline \multirow[b]{2}{*}{$\begin{array}{l}\text { Sample } \\
\text { code }\end{array}$} & \multicolumn{3}{|c|}{ Thermal Properties } & \multicolumn{4}{|c|}{ Solubility Properties } \\
\hline & $\begin{array}{l}\mathrm{T}_{\mathrm{g}} \\
\left({ }^{\circ} \mathrm{C}\right)^{\mathrm{a})}\end{array}$ & $\begin{array}{l}\mathrm{T}_{\mathrm{d} 1}{ }^{*} \\
\left({ }^{\circ} \mathrm{C}\right)^{\mathrm{b})}\end{array}$ & $\begin{array}{l}\mathrm{T}_{\mathrm{d} 2}{ }^{* *} \\
\left({ }^{\circ} \mathrm{C}\right)^{\mathrm{b})}\end{array}$ & $\begin{array}{l}\mathrm{H}_{2} \mathrm{O}, \\
\mathrm{MeOH}, \\
\text { EtOH, } \\
\text { Acetone, } \\
\text { ACN }\end{array}$ & THF & $\begin{array}{l}\mathrm{CHCl}_{3}, \\
\mathrm{CH}_{2} \mathrm{Cl}_{2}\end{array}$ & $\begin{array}{l}\text { DMF, } \\
\text { DMAc } \\
\text { DMSO, } \\
\text { NMP }\end{array}$ \\
\hline 1 & 188 & 470 & $\mathrm{n} / \mathrm{o}$ & - & ++ & ++ & ++ \\
\hline $3 a$ & 170 & 236 & 381 & - & ++ & ++ & ++ \\
\hline $3 b$ & 151 & 219 & 346 & - & ++ & ++ & ++ \\
\hline $4 a$ & 147 & 340 & $\mathrm{n} / \mathrm{o}$ & - & ++ & ++ & ++ \\
\hline $5^{a}$ & 138 & 351 & $\mathrm{n} / \mathrm{o}$ & - & ++ & ++ & ++ \\
\hline $5 \mathrm{~b}$ & 115 & 297 & $\mathrm{n} / \mathrm{o}$ & - & ++ & ++ & ++ \\
\hline $6 a$ & 182 & 372 & $\mathrm{n} / \mathrm{o}$ & - & + & ++ & ++ \\
\hline $6 b$ & 176 & 370 & $\mathrm{n} / \mathrm{o}$ & - & + & ++ & ++ \\
\hline
\end{tabular}

a) From DSC. b) From TGA; ${ }^{*}$ First major weight loss; ${ }^{* *}$ Second major weight loss; n/o: not observed.

“++” indicates solubility at $10 \mathrm{mg} / \mathrm{mL}$, “+” indicates solubility at $1 \mathrm{mg} / \mathrm{mL}$, “〜” indicates partial solubility at o.1 mg/mL, while “-” indicates no detectable solubility even at $0.1 \mathrm{mg} / \mathrm{mL}$ 
Table 3. Dimensional swelling behavior, mechanical properties and proton conductivities of 1,2,3-triazole-functionalized polysulfones (5b and 6b) and PBI before and after doping with phosphoric acid.

\begin{tabular}{|c|c|c|c|c|c|c|c|c|c|c|c|}
\hline \multirow[b]{2}{*}{$\begin{array}{l}\text { Sample } \\
\text { code }\end{array}$} & \multirow[b]{2}{*}{$\mathrm{ADL}^{*}$} & \multirow[b]{2}{*}{$\begin{array}{l}\mathrm{AU} \\
(\%)\end{array}$} & \multirow[b]{2}{*}{$\begin{array}{l}\text { WU } \\
(\%)\end{array}$} & \multicolumn{3}{|c|}{$\%$ variation } & \multirow[b]{2}{*}{$\begin{array}{l}\sigma^{+} \\
(\mathrm{mS} / \mathrm{cm})\end{array}$} & \multirow[b]{2}{*}{$\begin{array}{l}E_{\text {mod }} \\
(\mathrm{MPa})\end{array}$} & \multirow[b]{2}{*}{$\begin{array}{l}\delta_{\mathrm{y}} \\
(\mathrm{MPa})\end{array}$} & \multirow[b]{2}{*}{$\begin{array}{l}\delta_{\mathrm{b}} \\
(\mathrm{MPa})\end{array}$} & \multirow[b]{2}{*}{$\begin{array}{l}\text { El } \\
(\%)\end{array}$} \\
\hline & & & & Mass & Area & Volume & & & & & \\
\hline $5 \mathrm{~b}$ & - & - & - & - & - & - & - & 1438 & - & 65.1 & $5 \cdot 5$ \\
\hline $6 \mathrm{~b}$ & - & - & - & - & - & - & - & 1622 & - & 69.2 & 5.4 \\
\hline PBI & - & - & - & - & - & - & - & 2427 & 129.5 & 114.3 & 18.1 \\
\hline $\begin{array}{l}5 \mathrm{~b}-4.9 \\
\mathrm{H}_{3} \mathrm{PO}_{4}\end{array}$ & 4.9 & 70 & 12 & 132 & 46 & 92 & 34.5 & 332.7 & 12.3 & 2.4 & 19.3 \\
\hline $\begin{array}{l}6 \mathrm{~b}-5.0 \\
\mathrm{H}_{3} \mathrm{PO}_{4}\end{array}$ & 5.0 & 74 & 18 & 135 & 33 & 89 & $27 \cdot 3$ & 349 & 13 & 11.1 & 11.3 \\
\hline
\end{tabular}

* Obtained by ion chromatography. ${ }^{+}$Proton conductivity at $140{ }^{\circ} \mathrm{C}$ determined in a dry conductivity cell. $\mathrm{E}_{\mathrm{mod}}$ : elastic modulus; $\delta_{\mathrm{y}}$ : yield point; $\delta_{\mathrm{b}}$ : breaking strength; El: elongation at break.

\section{ASSOCIATED CONTENT}

Supporting Information

ATR-IR spectra of 3b, 5b and 6b. This material is available free of charge via the Internet at http://pubs.acs.org."

\section{AUTHOR INFORMATION}

\section{Corresponding Author}

*sara.cavaliere@umontpellier.fr

\section{Present Addresses}

†Anna Donnadio, Department of Pharmaceutical Sciences, University of Perugia, Via del Liceo 1, o6123 Perugia, Italy.

\section{Author Contributions}

The manuscript was written through contributions of all authors. / All authors have given approval to the final version of the manuscript.

\section{Funding Sources}

European Research Council under the European Union's Seventh Framework Programme (FP/2007-2013) / ERC Grant Agreement n. 306682.

\section{ACKNOWLEDGMENT}

Funding from the European Research Council under the European Union's Seventh Framework Programme (FP/2007-2013) / ERC Grant Agreement n. 306682 is acknowledged. 


\section{ABBREVIATIONS}

CuAAC, copper-catalyzed azide-alkyne cycloaddition; PEM, polymer electrolyte membrane; PEMFC, Proton Exchange Membranes Fuel Cells; PA, phosphoric acid.

\section{REFERENCES}

(1) Heravi, M. M.; Hamidi, H.; Zadsirjan, V. Recent Applications of Click Reaction in the Syntheses of 1,2,3-Triazoles. Curr. Org. Synth. 2014, 11, $647-675$.

(2) Totobenazara, J.; Burke, A. J. New Click-Chemistry Methods for 1,2,3-Triazoles Synthesis: Recent Advances and Applications. Tetrahedron Lett. 2015, 56, 2853-2859.

(3) Thibault, R. J.; Takizawa, K.; Lowenheilm, P.; Helms, B.; Mynar, J. L.; Fréchet, J. M. J.; Hawker, C. J. A Versatile New Monomer Family: Functionalized 4-Vinyl-1,2,3-Triazoles via Click Chemistry. J. Am. Chem. Soc. 2006, 128, 12084-12085.

(4) Dubey, N.; Sharma, M. C.; Kumar, A.; Sharma, P. A Click Chemistry Strategy to Synthesize Geraniol-Coupled 1,4-Disubstituted 1,2,3-Triazoles and Exploration of Their Microbicidal and Antioxidant Potential with Molecular Docking Profile. Med. Chem. Res. 2015, 1-15.

(5) Hein, J. E.; Fokin, V. V. Copper-Catalyzed Azide-alkyne Cycloaddition (CuAAC) and beyond: New Reactivity of Copper(i) Acetylides. Chem Soc. Rev. 2010, 39, 1302-1315.

(6) Rostovtsev, V. V.; Green, L. G.; Fokin, V. V.; Sharpless, K. B. A Stepwise Huisgen Cycloaddition Process: Copper(I)-Catalyzed Regioselective "Ligation" of Azides and Terminal Alkynes. Angew. Chemie - Int. Ed. 2002, 41, 2596-2599.

(7) Tornøe, C. W.; Christensen, C.; Meldal, M. Peptidotriazoles on Solid Phase: [1,2,3]-Triazoles by Regiospecific Copper(I)-Catalyzed 1,3-Dipolar Cycloadditions of Terminal Alkynes to Azides. J. Org. Chem. 2002, 67, 3057-3064.

(8) Meldal, M.; Tomøe, C. W. Cu-Catalyzed Azide - Alkyne Cycloaddition. Chem. Rev. 2008, 108, 2952-3015.

(9) Iha, R. K.; Wooley, K. L.; Nyström, A. M.; Burke, D. J.; Kade, M. J.; Hawker, C. J. Applications of Orthogonal "Click" Chemistries in the Synthesis of Functional Soft Materials. Chem. Rev. 2009, 109, 5620-5686.

(10) Qin, A.; Lam, J. W. Y.; Tang, B. Z. Click Polymerization. Chem. Soc. Rev. 2010, 39, 2522-2544.

(11) Lutz, J.-F. 1,3-Dipolar Cycloadditions of Azides and Alkynes: A Universal Ligation Tool in Polymer and Materials Science. Angew. Chemie Int. Ed. 2007, 46, 1018-1025.

(12) Johnson, J. A.; Finn, M. G.; Koberstein, J. T.; Turro, N. J. Construction of Linear Polymers, Dendrimers, Networks, and Other Polymeric Architectures by Copper-Catalyzed Azide-Alkyne Cycloaddition "Click" Chemistry. Macromol. Rapid Commun. 2008, 29, $1052-1072$.

(13) Bock, V. D.; Hiemstra, H.; van Maarseveen, J. H. CuI-Catalyzed Alkyne-Azide "Click" Cycloadditions from a Mechanistic and Synthetic Perspective. European J. Org. Chem. 2006, 2006, 51-68.

(14) Fournier, D.; Hoogenboom, R.; Schubert, U. S. Clicking Polymers: A Straightforward Approach to Novel Macromolecular Architectures. Chem. Soc. Rev. 2007, 36, 1369-1380.

(15) Alonso, F.; Moglie, Y.; Radivoy, G. Copper Nanoparticles in Click Chemistry. Acc. Chem. Res. 2015, 48, $2516-2528$.

(16) Dervaux, B.; Du Prez, F. E. Heterogeneous Azide-Alkyne Click Chemistry: Towards Metal-Free End Products. Chem. Sci. 2012, 3, 959-966.

(17) Hashemi, E.; Beheshtiha, Y. S.; Ahmadi, S.; Heravi, M. M. In Situ Prepared CuI Nanoparticles on Modified Poly(styrene-Co-Maleic Anhydride): An Efficient and Recyclable Catalyst for the Azide-Alkyne Click Reaction in Water. Transit. Met. Chem. 2014, 39, $593-601$.

(18) Nemati, F.; Heravi, M. M.; Elhampour, A. Magnetic Nano- $\mathrm{Fe}_{3} \mathrm{O}_{4} @ \mathrm{TiO}_{2} / \mathrm{Cu}_{2} \mathrm{O}$ Core-Shell Composite: An Efficient Novel Catalyst for the Regioselective Synthesis of 1,2,3-Triazoles Using a Click Reaction. RSC Adv. 2015, 5, 45775-45784.

(19) Hosseinnejad, T.; Fattahi, B.; Heravi, M. M. Computational Studies on the Regioselectivity of Metal-Catalyzed Synthesis of 1,2,3 Triazoles via Click Reaction: A Review. J. Mol. Model. 2015, 21, 1-37.

(20) Fazeli, A.; Oskooie, H. A.; Beheshtiha, Y. S.; Heravi, M. M.; Valizadeh, H. Green and Facile Synthesis of 1,4-Disubstituted 1,2,3-Triazoles via a Click Reaction of $\alpha$-Bromo Ketones, [bmim]N3 and Terminal Acetylenes Microwave Irradiation. Lett. Org. Chem. 2013, 10, 738-743.

(21) Billiet, L.; Fournier, D.; Du Prez, F. Step-Growth Polymerization and "click" Chemistry: The Oldest Polymers Rejuvenated. Polymer (Guildf). 2009, 50,3877-3886.

(22) Mirsafaei, R.; Heravi, M. M.; Ahmadi, S.; Moslemin, M. H.; Hosseinnejad, T. In Situ Prepared Copper Nanoparticles on Modified KIT-5 as an Efficient Recyclable Catalyst and Its Applications in Click Reactions in Water. J. Mol. Catal. A Chem. 2015, 402, 100-108.

(23) Sood, R.; Obadia, M. M.; Mudraboyina, B. P.; Zhang, B.; Serghei, A.; Bernard, J.; Drockenmuller, E. 1,2,3-Triazolium-Based Poly(acrylate Ionic Liquid)s. Polymer (Guildf). 2014, 55, 3314-3319.

(24) Sood, R.; Zhang, B.; Serghei, A.; Bernard, J.; Drockenmuller, E. Triethylene Glycol-Based poly(1,2,3-Triazolium Acrylate)s with Enhanced Ionic Conductivity. Polym. Chem. 2015, 6, 3521-3528.

(25) Mudraboyina, B. P.; Obadia, M. M.; Allaoua, I.; Sood, R.; Serghei, A.; Drockenmuller, E. 1,2,3-Triazolium-Based Poly(ionic Liquid)s with Enhanced Ion Conducting Properties Obtained through a Click Chemistry Polyaddition Strategy. Chem. Mater. 2014, 26, 1720-1726.

(26) Akbey, U.; Granados-Focil, S.; Coughlin, E. B.; Graf, R.; Spiess, H. W. 1H Solid-State NMR Investigation of Structure and Dynamics of Anhydrous Proton Conducting Triazole-Functionalized Siloxane Polymers. J. Phys. Chem. B 2009, 113, 9151-9160.

Kappe, C. O.; Van der Eycken, E. Click Chemistry under Non-Classical Reaction Conditions. Chem. Soc. Rev. 2010, 39, 1280-1290. 
Kappe, C. O. Microwave Dielectric Heating in Synthetic Organic Chemistry. Chem. Soc. Rev. 2008, 37, 1127-1139.

Appukkuttan, P.; Mehta, V. P.; Van der Eycken, E. V. Microwave-Assisted Cycloaddition Reactions. Chem. Soc. Rev. 2010, 39, $1467-1477$.

Gawande, M. B.; Shelke, S. N.; Zboril, R.; Varma, R. S. Microwave-Assisted Chemistry: Synthetic Applications for Rapid Assembly of Nanomaterials and Organics. Acc. Chem. Res. 2014, 47, 1338-1348.

Schuster, M. F. H.; Meyer, W. H.; Schuster, M.; Kreuer, K. D. Toward a New Type of Anhydrous Organic Proton Conductor Based on Immobilized Imidazole. Chem. Mater. 2004, 16, 329-337.

Kreuer, K. D.; Fuchs, A.; Ise, M.; Spaeth, M.; Maier, J. Imidazole and Pyrazole-Based Proton Conducting Polymers and Liquids. Electrochim. Acta 1998, 43, 1281-1288.

Subbaraman, R.; Ghassemi, H.; Zawodzinski, T. A. 4,5-Dicyano-1H-[1,2,3]-Triazole as a Proton Transport Facilitator for Polymer Electrolyte Membrane Fuel Cells. J. Am. Chem. Soc. 2007, 129, 2238-2239.

Kreuer, K.D.; Dippel, T.; Maier, J. Membrane Materials for PEM Fuel Cells: A Microstructural Approach. In Electrochemical Society Proceedings; Electrochemical Society, 1995; p. 95 (23), 241.

Zhou, Z.; Li, S.; Zhang, Y.; Liu, M.; Li, W. Promotion of Proton Conduction in Polymer Electrolyte Membranes by 1H-1,2,3-Triazole. J. Am. Chem. Soc. 2005, 127, 10824-10825.

Schuster, M.; Meyer, W. ; Wegner, G.; Herz, H..; Ise, M.; Kreuer, K..; Maier, J. Proton Mobility in Oligomer-Bound Proton Solvents: Imidazole Immobilization via Flexible Spacers. Solid State Ionics 2001, 145, 85-92.

Scharfenberger, G.; Meyer, W. H.; Wegner, G.; Schuster, M.; Kreuer, K.-D.; Maier, J. Anhydrous Polymeric Proton Conductors Based on Imidazole Functionalized Polysiloxane. Fuel Cells 2006, 6, 237-250.

Schmidt, C.; Schmidt-Naake, G. Proton Conducting Membranes Obtained by Doping Radiation-Grafted Basic Membrane Matrices with Phosphoric Acid. Macromol. Mater. Eng. 2007, 292, 1164-1175.

Guan, Y. S.; Pu, H. T.; Jin, M.; Chang, Z. H.; Wan, D. C. Preparation and Characterisation of Proton Exchange Membranes Based on Crosslinked Polybenzimidazole and Phosphoric Acid. Fuel Cells 2010, 10, 973-982.

Frutsaert, G.; Delon, L.; David, G.; Améduri, B.; Jones, D. J.; Glipa, X.; Rozière, J. Synthesis and Properties of New Fluorinated Polymers Bearing Pendant Imidazole Groups for Fuel Cell Membranes Operating Over a Broad Relative Humidity Range. J. Polym. Sci. Part A-Polymer Chem. 2010, 48, 223-231.

Campagne, B.; David, G.; Améduri, B.; Jones, D. J.; Rozière, J.; Roche, I. Novel Blend Membranes of Partially Fluorinated Copolymers Bearing Azole Functions with Sulfonated PEEK for PEMFC Operating at Low Relative Humidity: Influence of the Nature of the N-Heterocycle. Macromolecules 2013, 46, 3046-3057.

Campagne, B.; David, G.; Améduri, B.; Jones, D. J.; Rozière, J.; Roche, I. New Semi-IPN PEMFC Membranes Composed of Crosslinked Fluorinated Copolymer Bearing Triazole Groups and sPEEK for Operation at Low Relative Humidity. Int. J. Hydrogen Energy 2015, 40, 1679716813.

Campagne, B.; Silly, G.; David, G.; Ameduri, B.; Jones, D. J.; Roziere, J.; Roche, I. Anhydrous Proton Motion Study by Solid State NMR Spectroscopy in Novel PEMFC Blend Membranes Composed of Fluorinated Copolymer Bearing 1,2,4-Triazole Functional Groups and sPEEK. RSC Adv. 2014, 4, 28769-28779.

Tethered Polysulfone for DMFC. J. Memb. Sci. 2010, 362, 289-297.

Li, N.; Guiver, M. D.; Binder, W. H. Towards High Conductivity in Anion-Exchange Membranes for Alkaline Fuel Cells. ChemSusChem 2013, 6 , $1376-1383$.

Sanghi, S.; Tuominen, M.; Coughlin, E. B. Hybrid Inorganic-Organic Proton Exchange Membranes Containing 1H-1,2,3-Triazole Moieties. Solid State Ionics 2010, 181, 1183-1188.

Nulwala, H.; Takizawa, K.; Odukale, A.; Khan, A.; Thibault, R. J.; Taft, B. R.; Lipshutz, B. H.; Hawker, C. J. Synthesis and Characterization of Isomeric Vinyl-1,2,3-Triazole Materials by Azide-Alkyne Click Chemistry. Macromolecules 2009, 42, 6068-6074.

Green, M. D.; Salas-de la Cruz, D.; Ye, Y.; Layman, J. M.; Elabd, Y. A.; Winey, K. I.; Long, T. E. Alkyl-Substituted N-Vinylimidazolium Polymerized Ionic Liquids: Thermal Properties and Ionic Conductivities. Macromol. Chem. Phys. 2011, 212, 2522-2528.

Akutsu, F.; Inoki, M.; Sawano, M.; Kasashima, Y.; Naruchi, K.; Miura, M. Preparation and Characterization of Novel Aromatic Polyimides Having 4, 5-Di ( 1 , 3-Phenylene ) Imidazole Structure. 1998, 39, 6093-6098.

Abu-Thabit, N. Y.; Ali, S. A.; Javaid Zaidi, S. M. New Highly Phosphonated Polysulfone Membranes for PEM Fuel Cells. J. Memb. Sci. 2010, 360, 26-33.

Dimitrov, I.; Takamuku, S.; Jankova, K.; Jannasch, P.; Hvilsted, S. Polysulfone Functionalized With Phosphonated Poly ( Pentafl Uorostyrene ) Grafts for Potential Fuel Cell Applications. Macromol. Rapid Commun. 2012, 1368-1374.

Gaina, C.; Gaina, V.; Ionita, D. Chemical Modification of Chloromethylated Polysulfones via Click Reactions. Polym. Int. 2011, 60, $296-303$.

Avram, E.; Brebu, M. A.; Warshawsky, A.; Vasile, C. Polymers with Pendent Functional Groups. V. Thermooxidative and Thermal Behavior of Chloromethylated Polysulfones. Polym. Degrad. Stab. 2000, 69, 175-181.

Kappe, C. O. Controlled Microwave Heating in Modern Organic Synthesis. Angew. Chemie Int. Ed. 2004, 43, 6250-6284.

Kunal, K.; Robertson, C. G.; Pawlus, S.; Hahn, S. F.; Sokolov, A. P. Role of Chemical Structure in Fragility of Polymers: A Qualitative Picture. Macromolecules 2008, 41, 7232-7238. 
(56) Paul M. Hergenrother. The Use, Design, Synthesis and Properties of High Performance/High Temperature Polymers: An Overview. High Perform. Polym. 2003, 15, 3-45.

(57) Qin, Q.; McKenna, G. B. Correlation between Dynamic Fragility and Glass Transition Temperature for Different Classes of Glass Forming Liquids. J. Non. Cryst. Solids 2006, 352, 2977-2985.

(58) N. Kubota, T. S. Combustion Mechanism of Azide Polymer. Propellants, Explos. Pyrotech. 1996, 21, 160-165.

(59) Molnár, G.; Botvay, A.; Pöppl, L.; Torkos, K.; Borossay, J.; Máthé, Á.; Török, T. Thermal Degradation of Chemically Modified Polysulfones. Polym. Degrad. Stab. 2005, 89, 410-417.

(60) Dehaen W, B. V. A. Chemistry of 1,2,3-Triazoles. In Chemistry of 1,2,3-triazoles; Dehaen W, B. V. A., Ed.; 2015; Vol. 40, pp. 1-13.

(61) Lam, J. W. Y.; Dong, Y.; Cheuk, K. K. L.; Law, C. C. W.; Lai, L. M.; Tang, B. Z. Helical Conjugated Polymers: Synthesis, Stability, and Chiroptical Properties of Poly(alkyl Phenylpropiolate)s Bearing Stereogenic Pendants. Macromolecules 2004, 37, 6695-6704.

\section{ToC graphic}

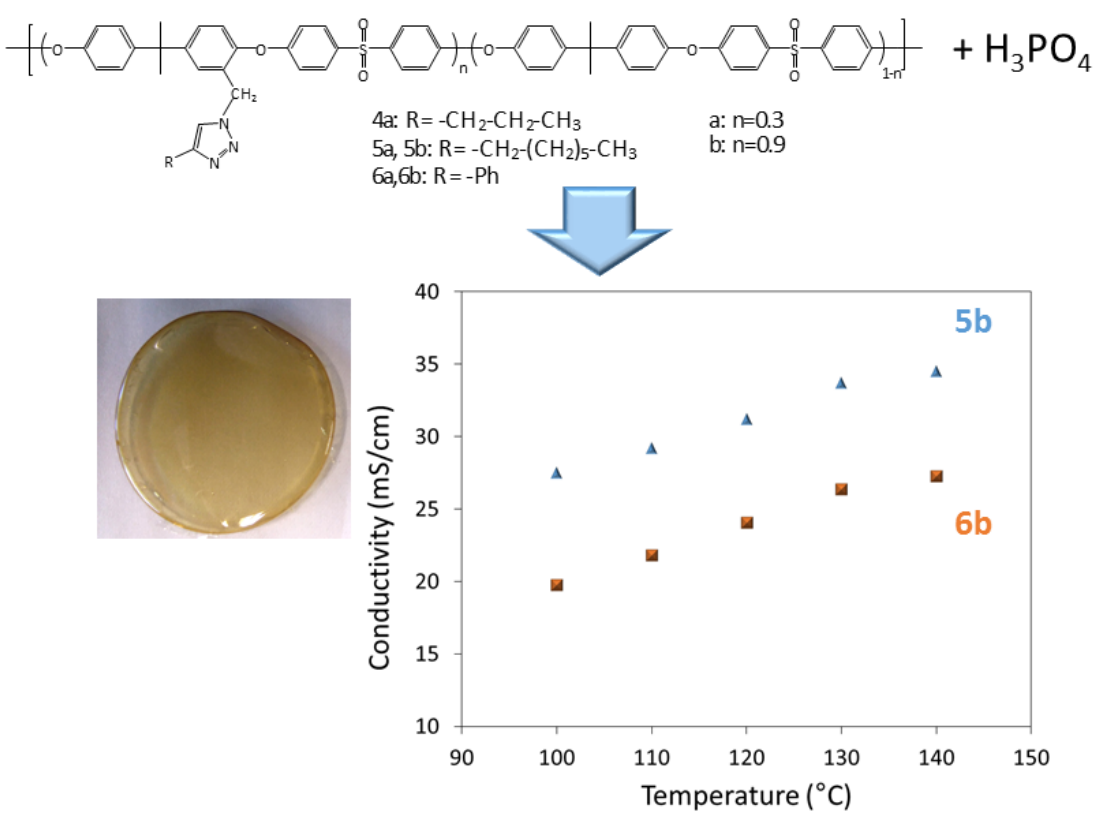

